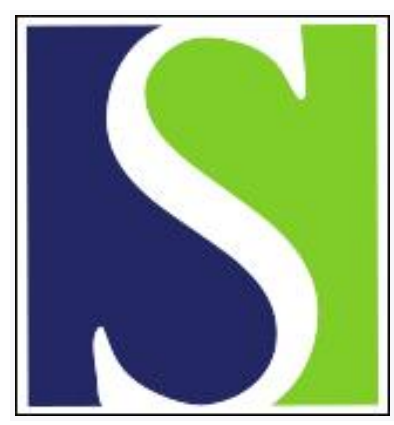

Scand J Work Environ Health 1975;1(3):139-172

https://doi.org/10.5271/sjweh.2850

Issue date: Sep 1975

Biological criteria for selected industrial toxic chemicals: a review.

by Lauwerys $\mathrm{R}$

Key terms: biological criterion; biological monitoring; industrial chemical; industrial toxic chemical; review; toxic substance

This article in PubMed: www.ncbi.nlm.nih.gov/pubmed/779026

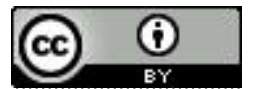




\title{
Biological criteria for selected industrial toxic chemicals: A review
}

\author{
by ROBERT LAUWERYS, M.D., D.Sc. ${ }^{1}$
}

LAUWERYS, R. Biological criteria for selected industrial toxic chemicals: A review. Scand. j. work environ. \& health 1 (1975) 139-172.

Key words: toxic substances, industrial chemicals, biological monitoring.

One of the main objectives of occupational medicine is to prevent the development of occupational diseases. In this respect the biological monitoring of workers exposed to various industrial chemicals may play an important role, either by detecting excessive exposure as early as possible before the occurrence of significant biological changes or by discovering biological disturbances when they are still reversible or have not yet caused any health impairment.

One must recognize that this method of early detection of industrial hazards has not yet reached an advanced stage of development, and the reasons are simple. A rational biological monitoring is only possible when sufficient toxicological information has been gathered on the mechanism of action and/or the metabolism of xenobiotics to which workers may be exposed. For many industrial chemicals relevant information is lacking however. Indeed new industrial chemicals are regularly introduced before any extensive toxicological study has been performed. Furthermore, when basic toxicological investigations (mechanism of action, me-

1 Unit of Industrial and Medical Toxicology, University of Louvain, Brussels, Belgium.

Reprint requests to: Prof. R. Lauwerys, Unite de Toxicologie Industrielle et Medicale, University of Louvain, 4 Clos Chapelle aux Champs, 12 Brussels, Belgium. tabolism) have suggested a potentially useful biological parameter (urinary metabolite, blood enzyme activity, etc.), other prerequisites such as the following must still be met before proposing its use for the routine monitoring of workers exposed to the chemical:

1. If a biological parameter is intended to evaluate the intensity of a biological disturbance (inhibition of plasma pseudocholinesterase, reduction of peak expiratory flow rate, etc.), some knowledge of the health significance of the biological change measured (e.g., correlation with brain true cholinesterase activity) should be available in order to propose a meaningful threshold value for the parameter.

2. If a biological parameter is proposed to evaluate the total uptake (lung, skin, digestive system, etc.) of a foreign chemical or its degree of retention in the organism [body burden $=$ (uptake $\times$ time) (elimination $\times$ time)], the relationship between these parameters (uptake, body burden) and the rate of variation of the biological parameter must also be known. It should be emphasized that the situation may be very complicated when the metabolic fate of the compound differs according to the route of entry, as has been demonstrated for ethylbenzene (86).

3. When a biological measurement is principally intended to evaluate uptake, the relationship referred to in no. 2 must hold for exposures below the maximum 
tolerable exposure; hence a biological threshold limit value (TLV) can be proposed.

4. For evident practical reasons a selected parameter should be sufficiently stable to allow storage of the biological samples for a certain period of time and it should be amenable to a nontime-consuming analysis by a not too sophisticated technique.

5. The precision and the accuracy of the analysis should be satisfactory. Several intercomparison programs for the analysis of industrial chemicals in biological material have indeed stressed the analytical difficulties associated with these measurements $(28,29,40,82,159,162,170$, 192).

For many currently used industrial chemicals one or all of the preceding prerequisites are lacking, which of course limits the possibilities of specific biological monitoring.

When such specific (or at least oriented) biological measurements are feasible, the approach offers important advantages over monitoring the air of the work place. The two main advantages are (a) that it takes into consideration absorption by all the routes, not only through the lungs, and (b) that it may consider individual differences in the susceptibility to the chemical or differences in its rate of absorption, distribution, biotransformation, and excretion. Each worker is thus his own integrator of the total exposure (181).

The purpose of this review is to discuss some industrial toxicological hazards for which, on the basis of current scientific knowledge, a biochemical parameter may be useful in either detecting functional perturbations at an early stage or evaluating the intensity of exposure. This paper does not deal with the physiological parameters (like lung function tests) in cases of exposure to lung irritants, but is limited to the chemical analyses which can be performed on biological material. However, although in many circumstances a biological parameter can be proposed, no meaningful biological TLV can yet be defined because clinical studies (on workers or on volunteers) are lacking or inadequate.
Before specific compounds are dealt with, some general remarks are relevant. When biological monitoring consists of sampling and analyzing urine, it is usually performed on "spot" specimens because routine collection of $24-\mathrm{h}$ samples from workers is impractical (94). It is therefore advisable to correct the results for the dilution of the urine. Two methods of correction have been used: (a) expression of the results per gram of creatinine or (b) adjustment to a constant specific gravity. Although there is no general superiority for creatinine adjustment over specific gravity, creatinine correction is better for very concentrated and very dilute samples (94). Furthermore, in the case of glucosuria and probably proteinuria, the specific gravity adjustment may give results that are too erroneous. In our laboratory my coworkers and I also use creatinine adjustment. (The average daily excretion of creatinine in adults is $1.7 \mathrm{~g}$.) Whatever the method of correction it should be stressed that analyses performed on too diluted a urine specimen (specific gravity less than 1.010) are not reliable. In some circumstances it may be feasible to report results in excretion rates (i.e., quantity/ time unit), which supposes the collection of urine during a well-defined period of time (one or a few hours). One must however recognize that this method, which is certainly more accurate than spot sample analysis, is usually too elaborate for the routine control of workers.

When the large interindividual variability and/or the high "background" level of the biological parameter selected makes the interpretation of a single measurement difficult, it is sometimes useful to analyze biological material collected before and after the exposure period. The change in the biological parameter due specifically to exposure can then be better assessed.

\section{BIOLOGICAL TESTS FOR ORGANIC SUBSTANCES}

The majority of volatile organic substances absorbed by inhalation or through the skin are partially eliminated unchanged with the expired air and partially metab- 
olized into more polar derivatives, which are excreted in the urine.

Usually the metabolism of organic substances in vivo is rapid, and the excretion of the compound and/or its metabolites is, with a few exceptions, complete within 2 or 3 days. Therefore, when a biological method is used for monitoring exposure to these substances, the biological medium to be analyzed (blood, urine, expired air) must be collected at well-defined time intervals after the beginning of exposure, usually at the end of a work shift or, as indicated earlier, before and after the work period.

Two approaches have usually been followed in evaluating exposure to volatile organic substances: (a) determination of the main metabolite in urine (which requires a knowledge of the biotransformation undergone by the chemical in vivo) and (b), more recently, measurement of the parent compound in the expired air.

\section{AROMATIC HYDROCARBONS}

\section{Benzene}

Benzene is one of the most, if not the most, toxic aromatic hydrocarbons. Its metabolism has been the object of detailed studies $(133,248,249,263,281,282,362)$.

A fraction of the absorbed benzene is excreted unchanged mainly in the expired air, partly in the urine. The remaining fraction is metabolized probably by the liver microsomal enzymes (fig. 1).

The first reaction catalyzed by these enzymes is the transformation into benzene epoxide, a very reactive intermediate that either binds directly to cellular constituents (DNA, proteins, etc.), and is suspected for being responsible for the myelotoxic action of benzene, or is further transformed into other benzene derivatives. Benzene epoxide may be transformed nonenzymatically into phenol, which is then

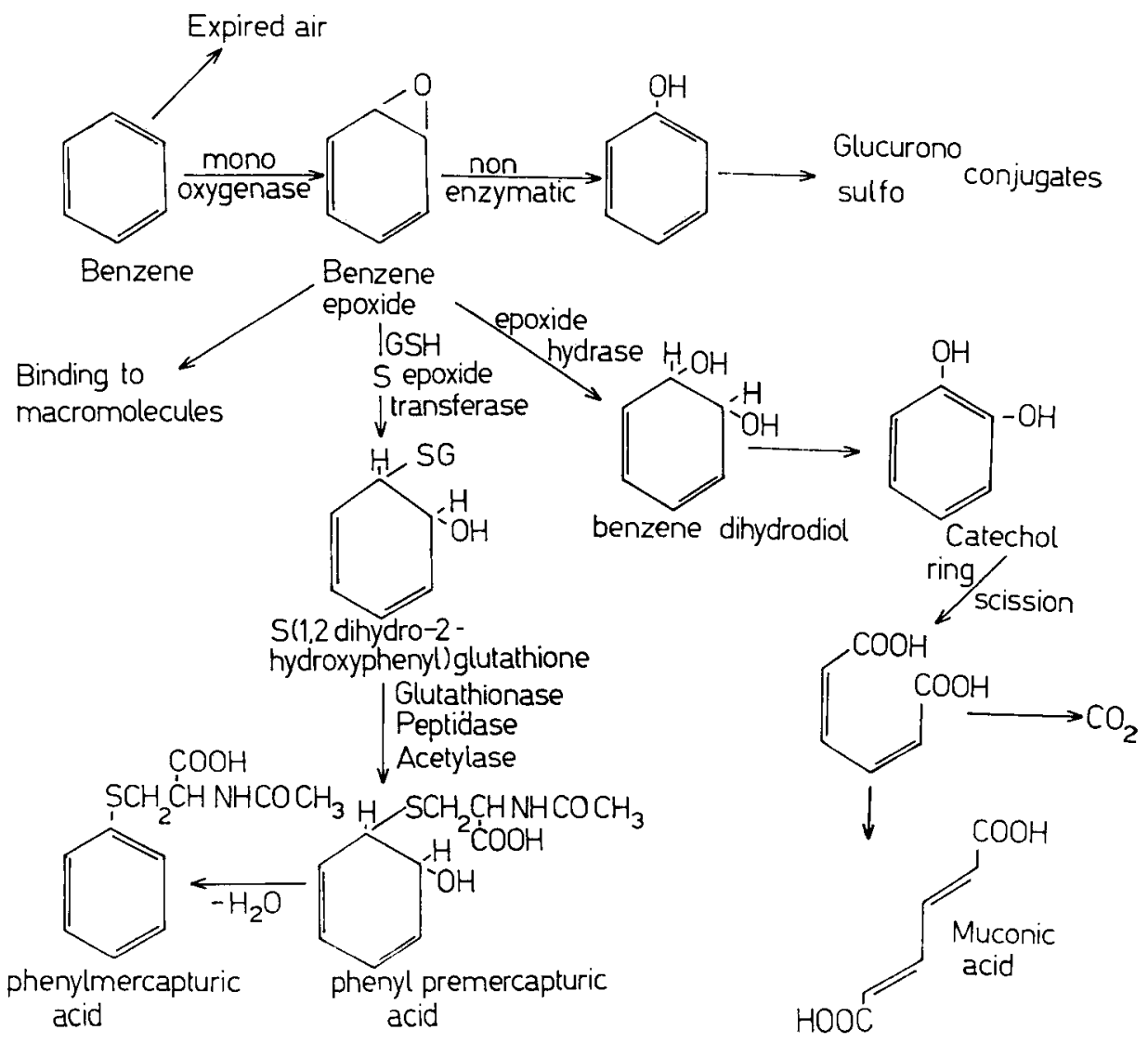

Fig. 1. Metabolic biotransformations undergone by benzene in vivo. 
conjugated with glucuronic acid or sulphate. The glucurono and sulfoconjugates of phenol are then excreted in the urine. The epoxide may also react with glutathion to yield S (1,2 dihydro-2-hydroxyphenyl) glutathione. The subsequent action of a glutathionase in the presence of a glutamine acceptor, a peptidase and acetyl $\mathrm{CoA}$ acetyltransferase, gives rise to a premercapturic acid, i.e., S (1,2 dihydro2-hydroxyphenyl) acetyl-L-cysteine) premercapturic acid, which is excreted as such in the urine. When urine is treated with mineral acids, the premercapturic acid is transformed into mercapturic acid. Under the action of the enzyme epoxide hydrase, trans 1,2 dihydro, 1,2 dihydroxybenzene is formed and is quickly transformed into catechol. This metabolite has also been considered responsible for the bone marrow lesions induced by benzene (176). After a ring scission reaction catechol is transformed into trans-trans muconic acid, excreted in the urine, and carbon dioxide, excreted with the expired air.

Phenol and its conjugates, phenylsulfate and phenylglucuronide, are the major metabolites of benzene $(79,299,362)$.

The knowledge of the fate of benzene in vivo has given rise to several biological exposure tests: (a) the ratio between inorganic and organic sulfates in urine, (b) concentration of total (free and conjugated) phenol in urine, (c) benzene determination in blood and in expired air (185).

The ratio between inorganic and organic sulfates in urine is normally more than $85 \%$. Exposure to benzene produces a decrease in this ratio since some metabolites of benzene are eliminated as sulfoconjugates. The decrease is roughly proportional to the degree of exposure (91, 328 ). In subjects who are free of any hepatic disease and who exhibit a normal sulfoconjugation capability the finding of a ratio below $70 \%$ indicates an exposure above $40 \mathrm{ppm}$; a ratio below $40 \%$ results from an exposure to more than $75 \mathrm{ppm}$. The sensitivity and the specificity of this test are thus very limited since an exposure on the order of $10 \mathrm{ppm}$ [time-weighted average recommended in 1974 by the National Institute for Occupational Safety and Health (NIOSH), U.S.A. (228)] would cause only a slight, and probably not sig- nificant, reduction in the ratio, and numerous hydroxylated organic chemicals are also excreted in urine as sulfoconjugates.

Contrary to substituted benzene derivatives (toluene, xylene, etc.) benzene gives rise to phenol in vivo, and therefore the measurement of urinary phenol excretion has been proposed as an exposure index. The sensitivity of this analysis is sufficient since workers not exposed to benzene or phenol excrete less than $20 \mathrm{mg}$ of phenol per gram of creatinine, on the average $5 \mathrm{mg}$ per gram of creatinine $(\mathrm{SD}=2.7$ $\mathrm{mg} / \mathrm{g}$ creatinine) [measurement performed with a specific gas chromatographic technique (41)]. After an 8-h exposure to an average benzene concentration of $10 \mathrm{ppm}$, the phenol concentration in urine collected at the end of a working shift would be, as a group average, around $70 \mathrm{mg}$ per liter $(79,328)$. The large difference between normal phenol concentrations in urine and those found when the timeweighted average exposure reaches $10 \mathrm{ppm}$ allows therefore an early detection of benzene exposure. It is true that there are interindividual variations in phenol excretion and that an isolated result has limited value in evaluating the hygienic conditions of the work place. More useful in this regard is the information drawn from the urine analysis of a group of workers or from the evolution of the phenol excretion on follow-up urine samples obtained at the beginning and at the end of the work day.

It should also be kept in mind that all the methods for urinary phenol analysis do not have the same specificity. The interpretation of the results must take care of this factor. In general the various colorimetric techniques $(46,245,264,328$, 356) lack specificity because some urinary cresols react also like phenol. It is therefore preferable to use a gas chromatographic method more specific and precise than the colorimetric methods $(41,195$, $343)$.

It should also be kept in mind that dermal application of phenol-containing preparations, exposure to phenol itself, and some gastrointestinal disorders favoring the bacterial degradation of tyrosine and phenylalanine (84) increase urinary phenol concentration.

The determination of benzene itself in 
blood and in expired air has also been proposed for the evaluation of the degree of exposure $(7,233,293,325,367)$. The lack of valuable information on the relationship between atmospheric and blood concentrations of benzene prevents the recommendation of a biological TLV for benzene in blood. Benzene concentrations in expired air after the end of exposure follow a more or less exponential decline (234). In fact one deals with several exponential curves which overlap each other and represent the clearance of the solvent from various body compartments. With a well-standardized protocol it is possible to demonstrate the existence of a satisfactory relationship between environmental exposure levels and benzene concentrations in exhaled breath $(293,306)$. However sufficient data, with which to define the conditions of breath analysis during routine monitoring (e.g., time of sampling) and the biological TLV for exhaled air, are still lacking.

\section{Toluene and xylene}

The metabolism of toluene and xylene is rather similar. In contrast to benzene these substances are not significantly transformed in phenol derivatives $(185,227)$.

The fraction of toluene which is not eliminated unchanged in the expired air is oxidized by transformation of the methyl radical into a carboxyl radical (by the mircosomal monooxygenase system), which is then conjugated with glycine to produce hippuric acid (fig. 2). The meta and para isomers of xylene are, like toluene, principally oxidized into toluic acids, which are then conjugated with glycine to produce meta and para methylhippuric acids. The ortho isomer, which is less frequently used, is also partially hydroxylated. The

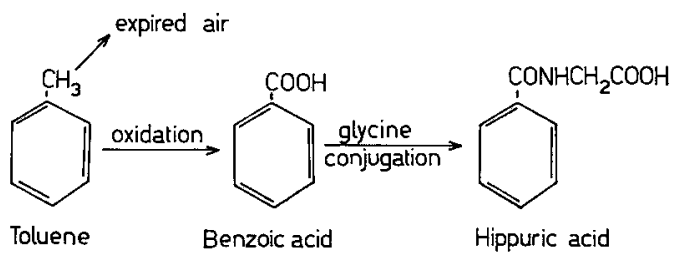

Fig. 2. Metabolic biotransformations undergone by toluene in vivo.
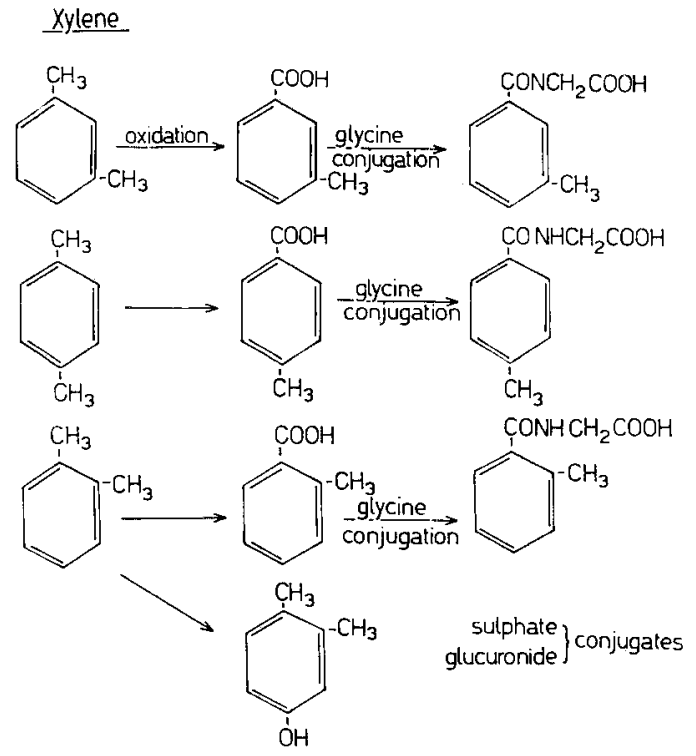

Fig. 3. Metabolic biotransformations undergone by xylene in vivo.

resulting xylenol is then conjugated with sulphate or with glucuronic acid. (fig. 3).

Several studies have demonstrated that there exists a significant correlation between the intensity of exposure to toluene and xylene and the amount of hippuric and methylhippuric acid excreted in the urine $(146,238,246)$.

As is the case for benzene, it must be pointed out that all the analytical procedures do not have the same specificity, a fact which may explain the variability of "normal" values of hippuric acid found by different laboratories.

My collegue and I have recently developed a specific gas chromatographic technique for measuring hippuric and methylhippuric acid in urine (42) and have found that, although large variations in urinary hippuric acid excretion exist between nonoccupationally exposed individuals (benzoïc acid is a constituent of many food items), its excretion rarely exceeds $1.6 \mathrm{~g} / 1$ (on the average $0.8 \mathrm{~g} / \mathrm{g}$ creatinine). Methylhippuric acid is not normally found in urine. This result agrees with those reported by other authors $(48,145)$.

According to Pagnotto and Lieberman (246), who measured hippuric acid by a nonspecific spectrophotometric technique, an exposure to $100 \mathrm{ppm}$ toluene [current atmospheric TLV proposed by the Ameri- 


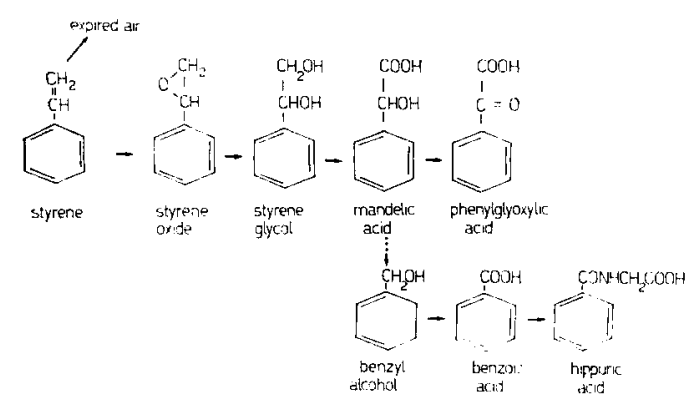

Fig. 4. Metabolic biotransformations undergone by styrene in vivo.

can Conference of Governmental Industrial Hygienists (ACGIH) in 1974 and by NIOSH in 1973 (227)] would produce a urinary hippuric acid content of about $4 \mathrm{~g}$ per liter in samples collected at the end of the work shift. Ogata et al. (238) who used a more elaborate and specific colorimetric technique (237), proposed slightly lower values. With their method an exposure to $100 \mathrm{ppm}$ of toluene would produce an average hippuric acid concentration of $2.8 \mathrm{~g}$ per liter (corrected for a specific gravity of 1.024) in urine collected in the second part of a 7-h exposure period. Their finding agrees with data reported by Ikeda and Ohtsuji (146).

Under the same conditions (7-h exposure to $100 \mathrm{ppm}$ ) urinary methylhippuric acid concentration is on the order of $2.5 \mathrm{~g}$ per liter (238).

The value of the expired air and blood determinations of toluene in evaluating the degree of exposure has also been tested. According to Astrand et al. (11) the best approach is to measure the content of solvent in alveolar air samples collected during exposure. At rest, the mean value for alveolar air concentration found during exposure to $100 \mathrm{ppm}$ of toluene is $18 \mathrm{ppm}$. In steady-state atmospheric toluene concentrations, alveolar air concentration increases as the atmospheric concentration increases. Determination of the toluene concentration in a venous blood sample has a very limited value in providing a correct view of the amount of toluene accumulated in the tissues. Furthermore the results of Astrand et al. (11) suggest that: "neither alveolar air samples nor venous blood samples taken at given intervals after the conclusion of a period of exposure can provide sufficiently accu- rate information on the average amount of solvent in inspired air at a working place or on the magnitude of an individual's uptake."

Nomiyama and Nomiyama $(233,234)$ found also that after the cessation of exposure women eliminated less toluene with the expired air than men.

\section{Mesitylene-1,3,5 -trimethylbenzene}

Mesitylene is a solvent which is oxidized in the organism to give 3,5 dimethylbenzoïc acid or mesitylenic acid (177), which is then conjugated with glycine. This metabolite can be recovered in the urine of workers exposed to mesitylene, but no data have yet been published which suggest a possible biological TLV.

\section{Styrene or vinylbenzene}

Styrene is extensively used in the manufacture of plastics. It enters the organism mainly through the lungs and the skin. Its metabolism has been thoroughly studied in man and can be summarized in the following manner (fig. 4). As for any volatile compound, a fraction of the dose absorbed (mostly via the lungs and the skin) is excreted unchanged with the expired air. What remains is oxidized into styrene oxide, which is hydrolyzed into styrene glycol. This metabolite is then oxidized in to mandelic acid. In man mandelic acid is either excreted as such in urine or further oxidized into phenylglyoxylic acid, which is also excreted by the kidneys $(18,241)$. When exposure is important (e.g., atmospheric concentration exceeding $100 \mathrm{ppm}$ ), the in vivo concentration of mandelic acid is sufficient to significantly stimulate another pathway, i.e., the decarboxylation of mandelic acid into benzyl alcohol, the precursor of hippuric acid (150).

Man however seems to have a relatively poor ability to convert mandelic acid to benzyl alcohol. Therefore in workers moderately exposed to styrene $(<100 \mathrm{ppm})$ only an increased urinary excretion of mandelic and phenylglyoxylic acid is usually found.

After styrene exposure the urinary pattern of excretion of the two main metabolites is different. The biological 
half-life of phenylglyoxylic acid in urine is greater than that of mandelic acid (150, 259), and it is a function of the intensity of exposure (259).

According to Härkönen et al. (132) workers exposed for $8 \mathrm{~h}$ to $200 \mathrm{ppm}$ of styrene excrete about $2 \mathrm{~g}$ of mandelic acid per liter of urine. Bardodej and Bardodejova $(17,18)$ have reported values $50 \%$ greater ( $3 \mathrm{~g} / \mathrm{l}$ ) for the same exposure. According to Götell et al. (121) $1 \mathrm{~g}$ of mandelic acid per liter of urine would indicate a timeweighted exposure of $50 \mathrm{ppm}$.

My coworkers and I have found that, when the phenylglyoxylic acid concentration in urine collected at the end of the working period does not exceed $350 \mathrm{mg} / \mathrm{g}$ creatinine, an exposure above the TLV proposed by the ACGIH in 1974 (100 ppm) is unlikely (259). It may also be interesting to control that the urine is emitted during an exposure period by measuring the ratio mandelic acid/phenylglyoxylic acid, which should then exceed a value of 2 (259). Götell et al. (121) reported that, when styrene exposure exceeds $150 \mathrm{ppm}$, the urinary levels of phenylglyoxylic and mandelic acids are no longer proportional to the solvent concentration in air.

Gas chromatographic and colorimetric techniques are available for measuring the two main metabolites in urine $(44,96$, 241).

Since there exists a significant correlation between the concentration of styrene in the alveolar air during exposure and the environmental concentration (243), the magnitude of the latter can also be evaluated by sampling the alveolar air at the work place [10 to $25 \mathrm{ppm}$ styrene in the alveolar air for an exposure of 100 ppm $(243,307)]$. Such a measurement, which must be performed at the site of exposure, has of course a limited interest. It does not integrate the total exposure during a time interval. It is simply an instantaneous measurement reflecting the intensity of exposure at the time of sampling. Stewart et al. (307) have indicated that, as for several halogenated solvents, there also exists a good correlation between the pulmonary clearance of styrene after the end of exposure and the intensity of the latter.

Three types of information would therefore be required to evaluate the average exposure concentration: (a) the expired air concentration, (b) the time interval between sampling and the end of exposure, and (c) the duration of the latter. According to Oltramare et al. (243) individual differences partly due to differences in body fat content, minute-ventilation, and cardiac output limit the interest of such an approach.

\section{HALOGENATED HYDROCARBONS}

\section{Trichloroethylene}

The amount of absorbed trichloroethylene that is not excreted unchanged with the exhaled breath is metabolized into chloral hydrate, which is then transformed into trichloroacetic acid and trichloroethanol. Both metabolites are excreted by the kidney (filtration and tubular secretion) (113). Trichloroethanol is partly conjugated with glucuronic acid (200) (fig. 5).

Several studies have investigated the interest of determining both metabolites in urine in order to evaluate environmental exposure to trichloroethylene $(231,255$, 326). The biological half-lives of trichloroethanol and trichloroacetic acid are different; that of the latter is greater than that of the former because of the binding of the trichlonoacetic acid to plasma proteins $(97,147,163,164,222,239)$. Müller et al. (222) evaluated the biological half-life of trichloroethanol at $12 \mathrm{~h}$ and that of trichloroacetic acid at $100 \mathrm{~h}$ in volunteers exposed to $50 \mathrm{ppm}$ of trichloroethylene ( $6 \mathrm{~h}$ a day for 5 days). Thus the trichloroethanol concentration in urine

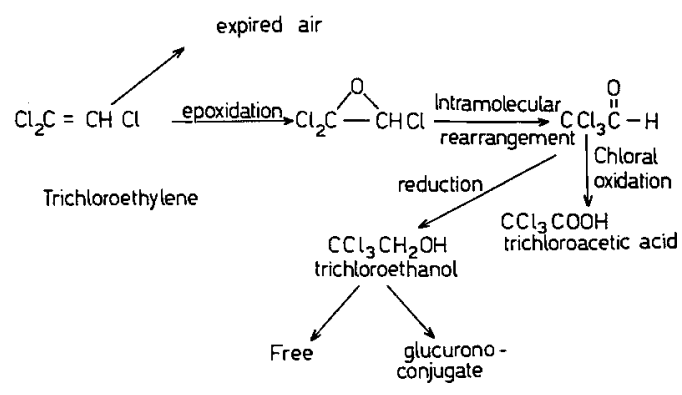

Fig. 5. Metabolic biotransformations undergone by trichloroethylene in vivo. 
reflects the environmental exposure of the same day even though that of trichloroacetic acid is still influenced by exposure from preceding days. Frant and Westendorp (107) calculated that exposure for several days to $100 \mathrm{ppm}$ trichloroethylene is associated with a urinary excretion of $200 \mathrm{mg}$ of trichloroacetic acid per liter. On the other hand Grandjean et al. (124) stated that the ratio of trichloroethylene in air (in ppm) over trichloroacetic acid in urine (in $\mathrm{mg} / \mathrm{l}$ ) is $3: 1$, which means that after exposure to $100 \mathrm{ppm}$ of trichloroethylene the urinary concentration of trichloroacetic acid would be approximately $30 \mathrm{mg} / \mathrm{l}$. Recently the subcommittee of the Hygiene Standards Committee of the British Occupational Hygiene Society (317) endorsed a recommendation that a level of $100 \mathrm{mg} / \mathrm{l}$ of trichloroacetic acid in urine (after the application of a correction to a specific gravity of 1.016) corresponded to $100 \mathrm{ppm}$ trichloroethylene in air, but details of the study on which this recommendation is based have not yet been published.

Several Japanese workers $(231,239,326)$ have recommended measuring both metabolites (total trichlorocompounds) to estimate trichloroethylene exposure. Indeed animal experiments recently confirmed by human observations $(97,148,164)$ have demonstrated that, when the atmospheric concentration of trichloroethylene exceeds $50-100 \mathrm{ppm}$, a greater fraction of trichloroethylene is transformed into trichloroethanol rather than into trichloroacetic acid.

Nomiyama and Nomiyama (232) also found a sex difference in trichloroethylene metabolism. Within $24 \mathrm{~h}$ after the end of exposure urinary excretion of trichloroacetic acid was greater in women than in men; the opposite was true for trichloroethanol. This observation was confirmed by Kimmerle and Eben (164).

Nomiyama (231) proposed a regression equation permitting the calculation of the average air concentration of trichloroethylene on the basis of the concentration of total trichlorocompounds in urine collected at different time intervals (up to 10 days) after the end of exposure.

Roughly one can say that a timeweighted average exposure of $100 \mathrm{ppm}$ of trichloroethylene (current ACGIH and
NIOSH TLV) is associated with an excretion of $500-600 \mathrm{mg}$ of total trichlorocompounds per gram of urine creatinine (urine collected at the end of the work period) (231). However, because of the prevalence of subjective complaints and psychological disturbances $(148,279)$ when the atmospheric concentration exceeds $\mathbf{5 0}$ $\mathrm{ppm}$, reduction of the TLV to this level seems justified. This level would correspond to a biological TLV of approximately $250 \mathrm{mg}$ per gram of creatinine for total trichlorocompounds $(148,222,231)$. It should be stressed that, as for any urinary metabolite, this relationship is only valid on a group basis because large individual differences exist in the rate of excretion of trichloroethanol and trichloroacetic acid.

Very sensitive and precise gas chromatographic techniques are now available for measuring both metabolites $(43,240)$.

Müller et al. (222) proposed determining trichloroacetic acid in plasma and trichloroethanol in whole blood rather than in urine. After the exposure of volunteers to $50 \mathrm{ppm}$ trichloroethylene for 5 days $(6 \mathrm{~h}$ a day) trichloroacetic acid in plasma reaches a level of $50 \mu \mathrm{g}$ per $\mathrm{ml}$ and that of trichloroethanol in whole blood, $2.3 \mu \mathrm{g} / \mathrm{ml}$.

Stewart and his collaborators $(309,313)$ extensively studied the pulmonary clearance of several aliphatic halogenated hydrocarbons and advocated this method of biological monitoring. According to this group of workers trichloroethylene concentration in expired alveolar air collected during exposure reflects the current atmospheric concentration (like for styrene), whereas that in alveolar air $16 \mathrm{~h}$ after the end of exposure (i.e., at the start of the next exposure period) correlates with the average airborne exposure.

Thus as a screening monitoring system Stewart et al. (313) have recommended the analysis of expired air before resuming work. Sixteen hours after an 8-h exposure to $100 \mathrm{ppm}$ of trichloroethylene (in tegrated exposure of $800 \mathrm{ppm}$ ) its concentration in alveolar air would not exceed $1 \mathrm{ppm}$. Such an approach - evaluation of the individual uptake of trichloroethylene by expired air analysis at the beginning of the next period of exposure - has also been recommended by Pfäffli and Backman (258). 


\section{Other halogenated hydrocarbons}

The capacity of humans to metabolize tetrachloroethylene $(148,239)$ and $1,1,1$ trichloroethane (methylchloroform) (305) is limited.

After repeated exposure to increasing concentrations of tetrachloroethylene the urinary excretion of total trichlorocompounds levels off rapidly at about $50 \mathrm{mg}$ per gram of creatinine when the airborne tetrachlroethylene concentration reaches 50 ppm (148).

Stewart and Rowe (305) also found that in humans exposed to $500 \mathrm{ppm}$ methylchloroform ( $7 \mathrm{~h}$ a day for 5 days) the amount of total trichloro-derivatives found in urine never exceeded one-tenth of the amount found after exposure to $200 \mathrm{ppm}$ trichloroethylene. This observation was recently confirmed by Seki et al. (287). They estimated that exposure to $50 \mathrm{ppm}$ of trichloromethylene and methylchloroform gives rise to a urinary excretion of 368 and $14 \mathrm{mg}$ of total trichlorocompounds per liter of urine, respectively.

Comparing the urinary excretion of trichloroacetic acid and trichloroethanol in rats and mice exposed for $8 \mathrm{~h}$ to $200 \mathrm{ppm}$ of various halogenated aliphatic hydrocarbons (1,1,1 trichloroethane; 1,1,2-trichloroethane; 1,1,1,2 - tetrachloroethane; $1,1,2,2$ tetrachloroethane, trichloroethylene and tetrachloroethylene), Ikeda and Ohtsuji (149) found that all compounds except 1,1,2-trichloroethane yielded an increased urinary excretion of both metabolites. This phenomenon was the most important for $1,1,1,2$ tetrachloroethane $(149,371)$ and trichloroethylene and much less important for tetrachloroethylene. In view of the infrequent use of 1,1,1,2 tetrachloroethane one can consider that the determination of total trichlorocompounds in urine has mainly a practical value for the evaluation of trichloroethylene exposure.

Although total trichlorocompounds in urine increase only slightly following exposure to methylchloroform, Seki et al. (287) believe that their determination could nevertheless be useful to evaluate exposure to this solvent. As indicated earlier, an exposure to $50 \mathrm{ppm}$ of methylchloroform would result in a urinary excretion of $15 \mathrm{mg}$ of total trichlorocompounds per gram of creatinine. However their data do not permit extrapolation to exposure around the current ACGIH TLV (250 ppm).

According to Grigorescu and Tora (cited by Boudene 1970) (36) the principal urinary metabolite of vinyl chloride is monochloroacetic acid, the concentration of which is related to the degree of exposure. No recent information is available on this subject, which deserves further research.

As in the case of trichloroethylene the determination of respiratiory concentration has also been proposed for estimating environmental exposure to several aliphatic halogenated hydrocarbons (carbon tetrachloride, tetrachloroethylene, methylchloroform, vinyl chloride, dichloromethane) $(19,76,268,302,303,304,308,310)$.

Some of these chemicals are also detectable in circulating blood (76) where their concentration should probably correlate with that in expired air. The data available are however insufficient for proposing meaningful biochemical TLVs for blood or expired air.

It is relevant to note here that an increased blood carboxyhemoglobin concentration has been observed in workers exposed to dichloromethane (methylene chloride) $(311,312)$. The carboxyhemoglobin level can reach 10 to $15 \%$ following $1 \mathrm{~h}$ of exposure to $1,000 \mathrm{ppm}$ dichloromethane.

\section{DIMETHYLAMIDES}

Dimethylamides have the following general structure:<smiles>[R]C(=O)N(C)C</smiles>

$\mathrm{N}$ methylformamide and $\mathrm{N}$ methylacetamide are the main metabolites resulting from the demethylation of the corresponding dimethylamide in vivo. They are excreted in the urine $(20,21,165,166)$. Preliminary results from a survey of workers exposed to dimethylformamide during the production of acrylic resin suggest that the determination of $\mathrm{N}$ methylformamide in urine could be useful in evaluating the degree of exposure (Lauwerys et al., unpublished results). On the 
basis of studies on human volunteers Kimmerle and Eben (166) concluded that a concentration of N-methylformamide above $50 \mathrm{mg}$ per $24-\mathrm{h}$ urine indicates exposures exceeding $20 \mathrm{ppm}$.

\section{ALCOHOLS, GLYCOLS, PHENOL} AND DERIVATIVES (see also pesticides)

Methanol can be determined in blood and in urine. Published cases of acute methanol poisoning, usually resulting from the absorption of adulterated liquor or methanol antifreeze, have indicated that there is some relationship between the severity of intoxication and the blood methanol concentration.

Human experiments have also shown that the methanol concentration in urine collected at the end of an exposure period seems to correlate with time and exposure levels (194). On the basis of these experiments in man and the observations made by Elkins (cited by Tréon) (336) in industry, one can roughly estimate that in the urine of workers exposed to $200 \mathrm{ppm}$ of methanol (current ACGIH TLV) one should find less than $5 \mathrm{mg}$ of methanol per liter of urine.

Oxalic acid is one of the metabolites of ethylene glycol $(110,213)$ and methylcellosolve (monomethyl ether of ethylene glycol) (230) which is excreted by the kidneys. The limited data available do not permit a proposal of a biological standard for this metabolite.

Almost $100 \%$ of the phenol absorbed through the lung and the skin is excreted in the urine within one day, mostly in a conjugated form $(242,262)$. Piotrowski (262) estimated that in workers exposed for $8 \mathrm{~h}$ to $1.3 \mathrm{ppm}\left(5 \mathrm{mg} / \mathrm{m}^{3}\right)$ or $5 \mathrm{ppm}$ $\left(19 \mathrm{mg} / \mathrm{m}^{3}\right.$ ) of phenol (current Soviet and ACGIH TLV) the excretion rate at the end of the exposure period would reach about 4.4 and $15.3 \mathrm{mg}$ per hour, respectively. This estimation agrees well with the observations of Ohtsuji and Ikeda (242). According to their regression line one should find approximately $300 \mathrm{mg}$ of phenol per gram of creatinine in urine samples collected toward the end of an 8-h exposure to $15 \mathrm{mg}$ phenol $/ \mathrm{m}^{3}$. The same authors found that neither urinary ethereal sulphate nor urinary ethereal glucuronide was a good index of phenol exposure.

\section{AMINO AND NITRO COMPOUNDS}

(see also pesticides)

Several aromatic amino and nitro compounds are methemoglobin producing agents, and exposure to these agents should be kept below the level producing change in the blood methemoglobin level. In normal subjects who were not occupationally exposed to methemoglobin producing substances and who had abstained from smoking for at least $12 \mathrm{~h}$ previously, Gobbi et al. (117) found a mean methemoglobin level of $1.16 \%(\mathrm{SD}=0.81 \%)$.

For aniline and nitrobenzene the determination of the main urinary metabolites - p-aminophenol and p-nitrophenol, respectively - is certainly a more sensitive method of monitoring than methemoglobin determination. After $6 \mathrm{~h}$ of exposure to an airborne vapor concentration of $1 \mathrm{ppm}$ of nitrobenzene (current ACGIH $T L V)$ the urinary concentration of p-nitrophenol reaches approximately $5 \mathrm{mg} / 1$ (261). A dangerous exposure to aniline is suspected when the $\mathrm{p}$-aminophenol concentration exceeds $50 \mathrm{mg} / 1$ (215). A reasonable biological TLV should probably be on the order of $10 \mathrm{mg} / 1$.

\section{PESTICIDES}

\section{Organophosphorus and carbamate insecticides}

The depression of plasma and/or erythrocyte cholinesterase is usually regarded as a good indice of the absorption of cholinesterase inhibiting pesticides (organophosphorus esters, $\mathrm{N}$ methyl or $\mathrm{N}$ dimethylcarbamate esters).

The various techniques available for measuring these enzymes have been reviewed elsewhere $(13,361,368)$.

Some pitfalls should be recognized. Inhibition of the enzymes by free active pesticides may occur during blood storage, and in that case cholinesterase activity is not a reflection of the true activity in vivo (342). On the other hand carbamylated cholinesterases and also some phosphorylated cholinesterases can be significantly reactivated during storage. The two kinds or error, further inhibition or partial recovery after sampling, must be 
considered when selecting the conditions of assay (technique, duration of storage, etc.). The selection of the enzyme activity to be determined (red blood cell or plasma) depends on the relative affinity of the pesticide for both enzymes. Usually, but there are several exceptions, plasma cholinesterase is more sensitive to inhibition by organophosphate and carbamate insecticides than the erythrocyte enzyme. Since there is a great interindividual variability in blood cholinesterase activity, it is certainly more meaningful to compare exposure values with preexposure levels. A $50 \%$ reduction in activity requires removal of the worker from exposure.

Although cholinesterase enzyme determinations are sufficiently sensitive and specific for monitoring programs (mostly if preexposure activities are known), they sometimes raise difficult problems for adequate sample conservation before analysis. Therefore in some circumstances it may be interesting to consider whether the search for a urinary metabolite may not be more practical.

Various dialkylphosphates which are hydrolytic metabolites of many organophosphorus esters can be measured in urine by gas chromatography (292). Skafik et al. (292) proposed such a measurement for human monitoring programs, but a biological threshold should then be established for each pesticide. Indeed it is clear that the amount of dimethylphosphate tolerable in urine should depend on whether the worker has been exposed to methylparathion or fenitrothion, both of which are dimethylphosphate esters but have a different degree of toxicity.

The determination of urinary 4-nitrophenol excretion has been demonstrated to be a reliable index of parathion $[0,0-$ diethyl 0 (4-nitrophenyl) phosphorothioate] parathion methyl and EPN [0-ethyl 0-(4nitrophenyl) phenylphosphonothioate] exposure $(9,95,111,223,270,369)$, even more sensitive as an absorptron index than blood cholinesterases. This metabolite can be readily measured by a colorimetric or a gas chromatographic procedure $(38,62$, $95,354)$. A biological threshold of $100 \mu \mathrm{g} / 1$ in urine has been proposed (215). This value has probably a very high margin of safety since excretion rates of more than
$100 \mu \mathrm{g} / \mathrm{h}$ have been found in sprayers exposed to parathion without symptoms of intoxication (369).

Hayes (134) concluded from the work of Arterberry et al. (9) that the absorption of parathion is tolerated without illness and with little or no reduction in cholinesterase activity as long as the concentration of p-nitrophenol in urine does not rise much above $2 \mathrm{mg} / \mathrm{l}$. Cases of poisoning have however been reported by Arterberry et al. (9) in which the p-nitrophenol excretion was lower than $2 \mathrm{mg} / \mathrm{l}(0.9,0.57$ and $1.6 \mathrm{mg} / \mathrm{l}$ ).

Results obtained by Roan et al. (270) indicate that the determination of ethyl- or methylparathion in serum samples via gas chromatography is even more sensitive than the urine p-nitrophenol measurement. For many other anticholinesterase pesticides [Abate or $0,0,0^{\prime}, 0^{\prime}$ tetramethyl $0,0^{\prime}$ thiodi-p-phenylene phosphorothioate; fenitrothion or 0,0-dimethyl 0-(3-methyl-4nitrophenyl) phosphorothioate; dicapthon or 0 (2-chloro-4-nitrophenyl) 0,0-dimethyl phosphorothioate; fenchlorphos or 0,0-dimethyl 0-(2,4,5-trichlorophenyl) phosphorothioate; dursban or 0,0 diethyl $0-(3,5,6-$ trichloro-2-pyridyl) phosphorothioate; carbaryl or 1-naphthyl methylcarbamate; 2 isopropoxyphenyl methylcarbamate, etc.] the main urinary metabolites in humans are known or suspected from animal experiments (thiodiphenol; p-nitrocresol; 2chloro-4-nitrophenol; 2,4,5 trichlorophenol; 3,5,6-trichloro-2-pyridinol, 1-naphthol; 2isoproxyphenol) and are amenable to analysis by unsophisticated techniques $(33,70$, 291). The measurement of these metabolites may therefore constitute the basis of a biochemical test of exposure. However, insufficient human data exist for the proposal of meaningful biological TLVs for the majority of these metabolites, and therefore more epidemiologic studies are required among workers exposed to these pesticides.

As Hayes (134) pointed out, both approaches, measurement of cholinesterase activity and pesticide metabolite determination in urine, give complementary information because metabolite excretion occurs rather rapidly while enzyme activity recovers slowly. Thus cholinesterase determination integrates the effects of exposure during a long time interval (several 
weeks) while metabolite measurement gives information on very recent exposure.

\section{Other pesticides}

Organochlorine pesticides can be determined in blood usually by gas chromatography $(64,65,224,247,314)$. Their plasma concentrations are a satisfactory index of total body burden. This has been well demonstrated in man or in laboratory animals for pp'DDT, lindane, dieldrin, endrin, and telodrin $(66,90,143,152,173,216,224$, 271, 370). According to Jager (152) the threshold level in the blood below which no signs or symptoms of intoxication occur is at $0.20 \mu \mathrm{g} / \mathrm{ml}$ for dieldrin and 0.015 $\mu \mathrm{g} / \mathrm{ml}$ for telodrin. Brown et al. (39) put the threshold level for dieldrin in the blood at $0.15 \mu \mathrm{g} / \mathrm{ml}$. Data obtained by Kolmodin-Hedman (173) suggest that exposure to lindane induces drug oxidation in man at plasma levels above $0.010 \mu \mathrm{g} / \mathrm{ml}$ and higher and that a plasma level of total DDT under $0.2 \mu \mathrm{g} / \mathrm{ml}$ would not modify drug metabolism. Determination of the serum lipoprotein pattern of workers exposed to lindane (detection of hyperalphalipoproteins) has also been recommended (173).

According to several authors $(85,193$, 369 ), the urinary excretion of dichlorodiphenylacetic acid (DDA) could be used as an indicator of exposure to DDT. Both colorimetric and gas chromatographic methods are suitable for its determination (193).

Some phenol derivatives used as herbicides (2 methyl-4,5-dinitrophenol or DNOC; 2 sec butyl 4,6-dinitrophenol or DNBP) undergo various metabolic transformations, among them nitroreduction. The determination of corresponding aminoderivatives in urine could constitute the basis of a biochemical test of exposure.

The fungicide pentachlorophenol, which is a strongly acidic phenol, is mostly excreted unchanged in human urine. A urinary concentration of pentachlorophenol below $10 \mathrm{mg}$ per liter seems tolerable. This compound can be measured by gas chromatography with flame ionization or with an electron-capture detector $(63,269)$. Tetrachlorohydroquinone can also be found in the urine of workers occupationally exposed to pentachlorophenol (3).

\section{BIOLOGICAL TESTS FOR INOR- GANIC AND ORGANO-METALLIC SUBSTANCES}

\section{ARSENIC}

Exposure to arsenic or its derivatives results in an increased urinary excretion of arsenic (260, 357). Initially Elkins (92) proposed a toleration of a urinary excretion below $1 \mathrm{mg}$ per liter, which corresponds to a TLV of $0.25 \mathrm{mg} / \mathrm{m}^{3}$ for $\mathrm{As}_{2} \mathrm{O}_{3}$.

However, since arsenic is now recognized as a human carcinogen, the NIOSH (226) has recommended that arsenic and/or its derivatives should not be detectable in workroom air. Therefore no increase of urinary arsenic above the "background" level $(<100 \mu \mathrm{g} / \mathrm{l})$ is acceptable $(92,118)$.

Arsenic determination in hair is considered unreliable for monitoring workers' exposure because it is difficult to distinguish between externally deposited arsenic and that systemically incorporated in the hair (357).

\section{BERYLLIUM}

Although the appearance of beryllium in urine may be useful to confirm current or previous exposure to this chemical, no firm relationship between the intensity of exposure and urinary excretion has been established $(74,87,172)$. Indeed it is even possible to find no beryllium in the urine of workers with pulmonary granulomatosis (172).

\section{CADMIUM}

Persons not occupationally exposed to cadmium usually excrete less than $4 \mu \mathrm{g} /$ of cadmium per gram of creatinine in urine (188, 196, 274, 348).

Exposure to cadmium results in an increased urinary excretion of the metal $(189,199)$. It is still debatable however whether the cadmium concentration in urine reflects cadmium uptake. Indeed it is well known that the development of tubulopathy following cadmium exposure is associated with a rise in cadmium excretion even if exposure does not increase $(1,158,189,274)$. Nevertheless, if one does 
not take into consideration persons already suffering from cadmium nephropathy and already excreting large amounts of proteins, there is a significant relationship between cadmium exposure and the cadimium concentration in urine $(189,210)$.

Since the TLV for cadmium (dust and fumes) in air is the object of debate and varies from one country to the other between $200 \mu \mathrm{g}$ and $10 \mu \mathrm{g} / \mathrm{m}^{3}$, it may be unwise to propose a biological TLV for cadmium in urine. It has been observed however that kidney lesion is absent when workers excrete less than $15 \mu \mathrm{g}$ per gram of creatinine $(189,210)$.

The measurement of specific proteins (lysozyme, ribonuclease, $\beta_{2}$-microglobulin, albumin) in urine or the determination of their renal clearances may be useful for the early detection of renal involvement following cadmium exposure $(109,274)$, but it should be stressed that such changes, when present, reflect a tissue injury which may be irreversible and should therefore not be tolerated.

\section{CARBON DISULFIDE}

Approximately $70 \%$ of the carbon disulfide retained in the organism is metabolized and excreted in urine as organic sulfates or other sulfur compounds like thiourea, thiocarbamide and 5-mercaptothiazolidone $(253,254,329)$.

These metabolites are probably responsible for the iodine azide reaction (2 $\mathrm{NaN}_{3}+\mathrm{I}_{2} \longrightarrow 3 \mathrm{~N}_{2}+\mathrm{NaI}$ ) catalyzed by the urine of exposed workers. This reaction has been proposed for the control of workers exposed to carbon disulfide $(77,347)$. It should be stressed that this analysis is not specific for carbon disulfide since other substances like dithiocarbamate fungicides (Thiram, Ziram, Zineb, etc.), antabuse, and mercaptobenzoimidazole, which yield an increased excretion of bivalent sulfur, influence the reaction 106, 250).

According to the method developed by Djurić et al. (77) the exposure coefficient calculated from urine voided at the end of a work shift should be above 6.5 when exposure does not exceed $20 \mathrm{ppm}$.

The same group of workers have recently proposed a test to detect those workers who could be hypersusceptible to the effects of carbon disulfide (78). After the oral administration of $0.5 \mathrm{~g}$ of disulfiram the amount of diethyldithiocarbamates (DDC) present in urine collected $5 \mathrm{~h}$ after administration was determined. Since they found that the DDC excretion was the lowest in a group of intoxicated workers, they speculated that the disulfiram test could be a useful tool in predicting the susceptibility of each individual to carbon disulfide.

\section{CARBON MONOXIDE}

Under stable conditions $\left(\mathrm{pO}_{2}\right.$, lung ventilation, etc.) there is an excellent correlation between the intensity and duration of exposure to carbon monoxide and the amount of carboxyhemoglobin in blood. The concentration of carbon monoxide in expired air is also a reflection of the amount of circulating carbon monoxide. Carbon monoxide not only substitutes itself for oxygen in the hemoglobin molecule but shifts to the left the oxyhemoglobin dissociation curve. This action, which is called the Haldane effect, increases tissue anoxia. Although the affinity of carbon monoxide for myoglobin is about five times lower than that of hemoglobin, the binding of carbon monoxide to myoglobin could play a role in explaining the symptoms of carbon monoxide intoxication by reducing the transfer of oxygen to the mitochondria of the muscle cells particularly in the myocardium. [A review of this subject has been presented elsewhere (190.)]

Other molecules can also bind carbon monoxide (like cyt. $P$ 450), but the reduction of oxidative metabolism in vivo following carbon monoxide exposure has not been confirmed (218).

Repeated exposures to carbon monoxide can also modify the permeability of the blood vessel endothelium (12).

The biological TLV for carbon monoxide in blood is still controversial. There is currently enough evidence to suggest that the two organs most susceptible to carbon monoxide exposure are the central nervous system and the cardiovascular system. However the relationship between a slight elevation of the carboxyhemoglobin 
level (e.g., from 1 to $5 \%$ ) and the occurrence of neurological or behavioral disturbances is not straightforward, and many investigations have given contradictory results. [A review of this subject has been presented elsewhere $(98,190)$.] The effect of acute carbon monoxide exposure on the myocardium seems well demonstrated, mostly in persons suffering from coronary heart disease. In these subjects a slight elevation of carboxyhemoglobin up to $5 \%$ already exerts some deleterious effects $(5,8)$. This observation raises the important question of whether a biological standard should take into consideration persons already suffering from certain diseases. Personally I think that the answer should be positive when the disease has as high a prevalence as ischemic heart disease.

Furthermore animal experiments have demonstrated that in addition to its acute effect on the myocardium carbon monoxide may, after repeated exposures, favor the development of atheromatosis. The results obtained by Astrup's group in Copenhagen are so convincing that it has been suggested that carbon monoxide is the main atherogenic agent of cigarette smoke $(12,169,353)$.

Since personal pollution by cigarette smoking is so prevalent, the observation leads to another important consideration, i.e., must work standards be more stringent than "environmental" standards? In the case of carbon monoxide I feel that the standard for industrial exposure should be developed to protect nonsmokers whatever the background exposure voluntarily tolerated by other workers because of their personal habits. In that case the maximum tolerable carboxyhemoglobin level in nonsmokers should be set at $5 \%$, which corresponds to the level reached after an 8-h exposure to $35 \mathrm{ppm}$ of carbon monoxide (225).

Numerous methods have been published for the determination of carboxyhemoglobin [For a review of the literature the reader can consult Blackmore (34) and Lambert et al. (178).] The first group of methods requires the determination of the volume of carbon monoxide present in a known volume of blood. If the hemoglobin content of this blood is also measured, the carboxyhemoglobin level (in the percentage of total hemoglobin) can be calculated since 1 mole of hemoglobin binds 4 moles of carbon monoxide. To this group of techniques belong the gasometric methods (55), the microdiffusion techniques with the reduction of palladium chloride (350), the gas chromatographic techniques (144), and the infrared absorption techniques (37).

The second group of methods includes the various spectrophotometric techniques from the most rapid and simple (359) to the most elaborate $(294,297)$. Unlike those of the first group, the spectrophotometric techniques allow a direct determination of the carboxyhemoglobin level without a preliminary determination of the blood hemoglobin content. My colleagues and I (45) have recently compared three different techniques for the determination of carboxyhemoglobin: (a) the microdiffusion technique of Vignoli et al. (350), (b) the infrared technique of Boudène et al. (37) and (c) the spectrophotometric technique of Commins and Lawther (56). Excellent correlations $(r>0.99)$ were found between the results obtained with the three techniques, but systematic differences were observed. This observation should be taken into account when results obtained by different techniques are interpreted.

\section{CHROMIUM}

The metabolism of chromium has not been extensively studied. After its absorption, mostly through the respiratory tract and to a lesser extent through the skin and the gastrointestinal tract, chromium is excreted quickly (14).

It seems that the chromium concentration in blood is not a valid index of exposure or body burden (16).

Chromium in urine appears to be more useful in the evaluation of exposure, but the information available on this subject is still very limited. The normal urinary chromium concentration is probably around $5 \mu \mathrm{g}$ per liter (151). Franzen et al. (108) have proposed a maximal allowable concentration of $25 \mu \mathrm{g}$ of chromium per liter of urine.

Techniques have been described for determining chromium in biological mate- 
rials $(68,102,123,202,251,337,340,358)$, but the normal values reported in the literature must be interpreted with caution because chromium analysis has not yet been well standardized (59).

\section{CYANIDES AND ALKYLNITRILES}

Absorption of hydrocyanic acid, cyanides or compounds (e.g., aliphatic nitriles) that can liberate $\mathrm{CN}^{-}$in vivo causes an increase of the thiocyanate concentration in plasma (257) and in urine (101). Since tobacco smoke contains $\mathrm{HCN}$, it is normal to find a higher plasma concentration of thiocyanate in smokers (between 100 and 150 $\mu$ moles per liter, i.e., between 5.8 and $8.7 \mathrm{mg}$ per liter) than in nonsmokers (between 20 and $50 \mu$ moles per liter, i.e., between 1.2 and $2.9 \mathrm{mg}$ per liter) (257). Elkins (92) places the normal urinary concentration of thiocyanate in smokers at approximately $9 \mathrm{mg}$ per liter. No extensive survey of thiocyanate concentrations in the biological material of workers potentially exposed to cyanides has been performed, but because of the influence of cigarette smoking there is much doubt that these measurements may be of any value for following exposure under normal working conditions (101).

\section{FLUORIDE}

Fluoride appears rapidly in the urine after it has been absorbed (58). The urinary fluoride concentration is an excellent indice of fluoride intake (157). The current ACGIH TLV for fluoride is 2.5 $\mathrm{mg} / \mathrm{m}^{3}$. It has been estimated that an $8-\mathrm{h}$ exposure to such an ambient concentration would result in an absorption of approximately $5 \mathrm{mg}$ of fluoride (142), corresponding to an end of shift urine fluoride concentration of about $4 \mathrm{mg}$ per liter. Since osteosclerosis would not be expected in persons whose urine contains no more than $4 \mathrm{mg}$ per liter (58), it is only necessary to ensure that the exposure conditons are such that the urinary excretion never exceeds $\mathbf{4 - 5} \mathbf{~ m g}$ per liter (88). It should however be pointed out that the Soviet TLV is $1 \mathrm{mg} / \mathrm{m}^{3}$, which corresponds probably to a urinary fluoride concentration of $2 \mathrm{mg}$ per liter, and that advanced kidney disease has been shown to reduce the urinary excretion of fluoride (58).

The fluoride concentration in urine can be determined easily with the fluoride specific ion electrode $(229,318,339)$.

\section{HYDRAZINE}

A fluorimetric method has been described recently for monitoring the plasma level of hydrazine (349). The level at which the biological threshold should be set is however unknown.

\section{INORGANIC LEAD}

The comparative merits of the various biological tests available for the evaluation of lead absorption have been often investigated $(23,61,71,116,131,182,211$, $289,300,332,346,355,365,373$ ).

I intend to present only a brief account of the current thinking regarding the validity of these tests. The following comments only apply to adult workers and not to children (environmental exposure).

The various biological changes that develop following lead exposure and that have been proposed for the monitoring of workers can be classified schematically into two categories (182): (a) those which

rable 1. Biological changes that have been proposed for monitoring the exposure of workers to lead.

\begin{tabular}{|c|c|}
\hline $\begin{array}{l}\text { Evaluation of lead } \\
\text { exposure or lead } \\
\text { body burden }\end{array}$ & $\begin{array}{l}\text { Evaluation of the } \\
\text { biological action } \\
\text { of lead }\end{array}$ \\
\hline $\begin{array}{l}\text { Lead in blood } \\
\text { Lead in urine } \\
\text { Lead in urine after } \\
\text { administration of a } \\
\text { chelating agent } \\
\text { Lead in hair }\end{array}$ & $\begin{array}{l}\text { Hemoglobin } \\
\text { Hematocrit } \\
\text { Stippled cells } \\
\text { Coproporphyrins } \\
\text { in urine } \\
\text { Free erythrocyte } \\
\text { porphyrins } \\
\text { Porphobilinogen } \\
\text { in urine } \\
\delta \text {-aminolevulinic } \\
\text { acid (ALA) in } \\
\text { urine } \\
\text { ALA dehydratase } \\
\text { in erythrocytes }\end{array}$ \\
\hline
\end{tabular}


not useful for monitoring workers exposed to lead because usually its increase does not precede the development of clinical signs of intoxication (116). This parameter is therefore not sensitive enough.

$\delta$-aminolevulinic acid in urine. Because of the inhibition of $\delta$-aminolevulinic acid dehydratase (ALA-D) by lead $\delta$-aminolevulinic acid in urine (ALA-U) accumulates in the organism and is excreted in greater amounts.

Cramer and Selander (61) demonstrated that there is an excellent correlation $(\mathrm{r}=0.92)$ between ALA-U and the amount of lead excreted in urine following treatment with penicillamine. They therefore concluded that ALA-U reflects the amount of metabolically active lead in the organism.

Several workers have also found a satisfactory correlation between ALA-U and $\mathrm{Pb}-\mathrm{B}(61,130,191)$ or $\mathrm{Pb}-\mathrm{U}(23,71$, 300 ). Following the administration of a chelating agent, ALA-U excretion also follows the changes in $\mathrm{Pb}-\mathrm{B}$ (351).

A significant increase in ALA-U excretion occurs at approximately the same $\mathrm{Pb}-\mathrm{B}$ level as coproporphyrinuria, i.e., $40 \mu \mathrm{g}$ per $100 \mathrm{ml}(191)$. The sensitivity of this test is therefore sufficient for detecting workers overexposed to lead.

It seems however that after the cessation of exposure $\mathrm{Pb}-\mathrm{B}$ and $\mathrm{Pb}-\mathrm{U}$ return faster to "normal" or "acceptable" values than ALA-U (278, 289).

The specificity of the ALA-U test is certainly better than that of coproporphyrinuria $(24,112,300)$. Thus Basin (24) found, among 20 subjects suffering from various pathologic conditions (cirrhosis, acute ethylism, malignant hemopathies), a normal concentration of ALA-U but increased coproporphyrinuria excretion.

It is well known that a marked increase of ALA-U can also be found in acute intermittent porphyria (129) and in hereditary tyrosinemia (115), but the prevalence of these diseases is small.

In control individuals ALA-U does not exceed $4.5 \mathrm{mg}$ per gram of creatinine. A concentration around $15 \mathrm{mg}$ per gram of creatinine is a sign of overexposure to lead corresponding to a $\mathrm{Pb}-\mathrm{B}$ of $70 \mu \mathrm{g}$ per 100 ml (191).

Chromatographic $(67,212,319,364)$ and nonchromatographic $(122,183,334,352)$ methods are available for ALA-U determination in urine. The validity of some of these techniques has been critically evaluated (272).

The acidified urine can be stored at room temperature in darkness for several weeks (272).

$\delta$-aminolevulinic acid dehydratase. For the last 10 years the possibility of measuring the enzyme ALA-D directly has been considered since its inhibition (at least in critical tissues) is responsible for the excessive urinary excretion of ALA- $U$ following lead exposure. Indeed one knows since the work of Lichtman and Feldman (203) that the erythrocyte enzyme ALA-D is inhibited by lead, and this observation has been confirmed by many authors $(23,35,71,72,136,137,138)$.

ALA-D is highly sensitive to inhibition by lead (137). There is an excellent negative correlation between ALA-D activity and the concentration of lead in blood (with the $\mathrm{Pb}-\mathrm{B}$ range 10 to $60 \mu \mathrm{g}$ per $100 \mathrm{ml}$ ).

Depression of ALA-D activity in erythrocytes is not only a sensitive but also a specific index of exposure to lead since in workers occupationally exposed to two other heavy metals, i.e., cadmium and mercury, no reduction of ALA-D activity has been observed $(184,187)$.

It is interesting to note that ALA-D activity in human blood also decreases with the elevation of blood ethanol but returns to normal at the same rate as the ethanol level (219).

Until recently there was doubt whether the observed inhibition of ALA-D activity in peripheral blood by lead was an in vivo phenomenon or merely a result of membrane bound lead getting access to the intracellular enzyme as a result of hemolysis in the test tube required for determining ALA-D activity. In other words, the inhibition of erythrocytic ALA-D, as measured by the enzyme assay in test tubes, could be an in vitro artifact, reflecting only the concentration of lead in the circulating blood but not the true activity of this enzyme in the intact erythrocytes. My colleagues and I (273) recently demonstrated that the decrease of ALA-D in human erythrocytes measured under usual environmental and occupational exposure to lead $(\mathrm{Pb}-\mathrm{B}<120 \mu \mathrm{g}$ per $100 \mathrm{ml})$ is a 
true reflection of the enzyme activity in vivo.

Contrary to the response of free erythrocyte porphyrins, depression of ALA-D activity following lead exposure occurs with no demonstrable time lag (332).

Although there is no doubt that ALA-D is currently the most sensitive indicator of lead effect, quickly followed by FEP, its high degree of sensitivity (no threshold below which the enzyme is not inhibited) and the technical problem raised for its correct determination (in particular conservation of the blood sample at $0^{\circ} \mathrm{C}$ for a limited time interval) (30) limits its usefulness for the monitoring of workers.

In summary I recommend two tests for the routine monitoring of lead workers: $\mathrm{Pb}-\mathrm{B}$ and ALA-U (which is more specific than coproporphyrinuria). The first $(\mathrm{Pb}-\mathrm{B})$ reflects the absorption of lead and the second (ALA-U), its biological action. When only one test must be selected, I recommend ALA-U, which evaluates exposure and effect, is simpler to perform accurately than $\mathrm{Pb}-\mathrm{B}$, and does not entail any risk of sample contamination. It should be kept in mind that these recommendations onily apply to the monitoring of workers and not to the evaluation of environmental exposure to lead. In the latter case more sensitive tests (ALA-D, FEP) than ALA-U should be preferred.

\section{TETRAETHYLLEAD}

$\mathrm{Pb}-\mathrm{B}$ concentration is not a good index of tetraethyllead absorption. It is suggested to follow workers exposed to alkyllead derivatives by measuring lead in urine ( $\mathrm{Pb}-\mathrm{U})$ (104). The American Industrial $\mathrm{Hy}-$ giene Association has proposed the following criteria (Hygienic Guide Series 1963): $\mathrm{Pb}-\mathrm{U}:>0.11 \mathrm{mg}$ per liter: exposure is above normal; $\mathrm{Pb}-\mathrm{U}$ : $0.15 \mathrm{mg}$ per liter: the worker should be moved to an area of less exposure.

This proposal seems logical since Foa et al. (105) always observed $\mathrm{Pb}-\mathrm{U}$ levels in excess of $200 \mu \mathrm{g}$ per liter in cases of intoxication by tetraethyllead.

The activity of the blood enzyme ALA-D is also reduced in men working with lead alkyls (217).

\section{MANGANESE}

Manganese-loaded subjects do not excrete significant amounts of manganese in the urine $(60,207)$. Fecal elimination, probably following biliary excretion $(54,171,330)$, constitutes the main route of manganese excretion in man (207). The usefulness of analyzing urine for manganese as a means of evaluating occupational exposure is therefore doubtful. However Tanaka and Lieben (327) found that on a group basis the urinary manganese concentration of exposed workers shows a rough correlaition to the average air concentration. Normal adults excrete between 1 and $8 \mu \mathrm{g}$ of manganese per liter of urine. Since EDTA has been shown to mobilize manganese and to increase its urinary excretion $(252,360)$, analysis of urine after EDTA administration could be useful to confirm the existence of an increased manganese body burden. Further work is however required to confirm the validity of this test.

Jonderko and his collaborators (155) found a significant correlation $(r=0.50)$ between manganese in serum and the duration of employment in a manganese alloy foundry. They proposed $20 \mu \mathrm{g}$ per $100 \mathrm{ml}$ of serum as the threshold value of manganese retention. They found however that the increase in manganese concentration in blood appears at the earliest after 4 years of exposure and quickly falls when exposure is ended even in workers with signs of poisoning. Penalver (252) expressed doubts about the usefulness of manganese determination in blood. Furthermore Mahoney and Small (206) reported that manganese is rapidly cleared from the plasma and reappears bound in red cells. It would therefore be more logical to measure manganese in whole blood rather than in serum.

The feasibility of measuring blood manganese levels as an index of exposure should deserve further investigation.

In summary no valid biological test can yet be proposed to evaluate manganese exposure although manganese determination in stools has been suggested by a Soviet worker (154).

Techniques have been proposed for determining manganese in biological samples $(47,53,207,324,331,345)$. 


\section{INORGANIC MERCURY}

The determination of total mercury in urine is routinely used as a means of evaluating the extent of exposure to mercury vapor. It is recognized that there are significant interindividual variations in mercury excretion in urine, but several investigations have demonstrated that on a group basis the biological factor reflects the importance of mercury exposure (93, $127,156,186,266,298)$. The allowable concentration of inorganic mercury in urine of exposed workers is still unsettled. Elkins (92) suggested the value of 200 to $250 \mu \mathrm{g}$ per liter. The relationship between mercury concentration in air and urine obtained by Smith et al. (298) indicates that this excretion would result from an average exposure to $0.1 \mathrm{mg} / \mathrm{m}^{3}$. The ACGIH TLV for mercury vapor has however been recently reduced to $0.05 \mathrm{mg} / \mathrm{m}^{3}$, which on the basis of Smith's finding (298) corresponds to a urinary concentration of approximately $100 \mu \mathrm{g} /$ liter. Other data (186) suggest however that the urinary excretion of a group of workers exposed to $0.05 \mathrm{mg} / \mathrm{m}^{3}$ would be lower and probably closer to $50 \mu$ g per liter than $100 \mu \mathrm{g} /$ liter. The observations are in perfect agreement with those of Bell et al. (27), who found that the air/urine relationship $\left(\mathrm{mg} / \mathrm{m}^{3}\right.$ and $\left.\mathrm{mg} / \mathrm{liter}\right)$ approximates 1 to 1 . It was therefore recommended (186) that, if a group of workers exposed to inorganic mercury excretes more than $50 \mu \mathrm{g} / \mathrm{l}$, corrective industrial hygiene measures should be initiated. The California Bureau of Occupational Health reached the same conclusion. It should be stressed that several factors may influence the results of mercury measurement in urine, and serious consideration should be given to them when interpreting the results, i.e., (a) the reliability of the analytical method selected as used by the laboratory $(57,192)$, (b) the risk of urine contamination when instructions are not given to employees (hand washing, work clothes removal, etc.) before voiding specimens, (c) loss of mercury by volatilization when bacterial growth is not prevented during storage (204) or by adsorption on the container wall (338), (d) the existence of other sources of mercury exposure than the accupational ones, e.g., the use of mercurous chloride as a laxative (69), skin application of mercurial preparations (antiseptic soap, cosmetics, etc. $(22,209,341)$ and recent dental filling. The failure to recognize the influence of these factors, as well as the difficulty to evaluate correctly the timeweighted average exposure $(25,26)$, may explain the apparent lack of correlation between the degree of exposure and the urinary concentration of mercury for a single worker.

Recently it has been proposed (135) to measure separately elemental mercury, stannous-chloride-reducible (ionic) mercury, and total mercury in urine (elemental, ionic but free and bound mercury). The hypothesis behind such a proposal is that, as long as the rate of exposure does not exceed the rate at which the body can oxide mercury and excrete it in the urine in a bound form, the rate of exposure appears to have a margin of safety. This hypothesis deserves further research work.

\section{ALKYLIMERCURY DERIVATIVES}

The urinary output of mercury is not a very useful index of alkylmercury compound exposure, which represents more of an environmental hazard than an occupational one.

On the other hand blood mercury concentration is a better index of the body burden of alkyl mercury derivatives (15).

An international committee of experts (267) has proposed that the blood mercury concentration in individuals exposed to ethyl and methyl mercury compounds should not exceed $10 \mu \mathrm{g}$ per $100 \mathrm{ml}$, but according to Skerfving (296) neurological manifestations can already occur at this level.

\section{NICKEL CARBONYL}

The normal average values for nickel concentration in urine reported in the literature are quite variable and range from 2.3 to $40 \mu \mathrm{g}$ per liter $(151,168,214,235,256$, $320,322,335)$. Sunderman (323) proposed that workers be treated with the chelating agent sodium diethyldithiocarbamate when nickel concentration in urine exceeds $100 \mu \mathrm{g}$ per liter. The American Industrial 
Hygiene Association (4) considers that urinary concentrations below $0.25 \mathrm{mg}$ per liter indicate a mild exposure and that urinary concentrations above $0.5 \mathrm{mg}$ per liter suggest a severe exposure.

Spectrophotometric $(220,321)$ and atomic absorption procedures $(235,283,320)$ have been described for measuring nickel in biological material.

\section{SELENIUM}

Reviewing the early literature data on selenium, Patty (250) concluded that its urinary excretion parallels intake. Therefore selenium in urine is a valid test of exposure. The average concentration in persons not occupationally exposed is 0.03 mg per liter $(128,301)$. For workers a biological TLV of $0.1 \mathrm{mg} / \mathrm{l}$ has been proposed (250).

\section{THALLIUM}

It is well known that acute and chronic intoxication by thallium can be confirmed by measuring its urinary concentration (32). To my knowledge the biological TLV corresponding to a time-weighted average exposure of $0.1 \mathrm{mg} / \mathrm{m}^{3}$ (ACGIH 1974) has not been determined.

\section{INORGANIC TIN}

It has been suggested that the urinary concentration of tin can give a rough estimate of the amount absorbed (141, 161, 284 ), but, since inorganic tin is not an important industrial hazard, not much effort has yet been devoted to studying extensively the relationship between occupational exposure and the concentration in biological material.

Schroeder et al. (284) estimated that the normal urinary excretion of tin in man ranges from 0 to $40 \mu \mathrm{g} / 24 \mathrm{~h}$ (average $23 \mu \mathrm{g} / 24 \mathrm{~h})$.

\section{VANADIUM}

Some reports have indicated that exposure to vanadium results in an increased concentration of the metal in urine and/or in blood (153, 201, 295). Lewis (201) examined 24 men exposed to vanadium for more than 6 months (atmospheric concentration of vanadium from 0.097 to $0.925 \mathrm{mg} / \mathrm{m}^{3}$ ). The mean urinary concentration of vanadium in these workers was $46.7 \mu \mathrm{g}$ per liter against $11.6 \mu \mathrm{g}$ per liter in a control group. Sjöberg and Rigner (295) also observed an increased blood and urine vanadium concentration in workers who had been exposed to vanadium pentoxide.

Zenz and Berg (372) exposed volunteers to $0.2 \mathrm{mg} / \mathrm{m}^{3}$ vanadium pentoxide for $8 \mathrm{~h}$ and detected an increased urinary concentration of vanadium which was maximum 3 days after exposure. Not enough information is available however to conclude whether vanadium concentration in urine is correlated with air concentration, and therefore no biological TLV can yet be proposed for this parameter.

Mountain (221) and his colleagues also proposed to determine the cystine content of the fingernails, which decreases with chronic exposure to vanadium.

\section{REFERENCES}

1. ADAMS, R. G., HARRISON, J. and SCOTT, P. The development of cadmium induced proteinuria, impaired renal function and osteomalacia in alkaline battery workers. Q. j. med. 38 (1969) 423.

2. ALBAHARY, G., TRUHAUT, R., BOUDENE, C., DESOILLE, $H$. Le dépistage de l'imprégnation saturnine par un test de mobilisation du plomb. Presse med. 69 (1961) 2121.

3. AHLBORG, U. G., LINDGREN, J. E. and MERCIER, M. Metabolism of pentachlorophenol. Arch. toxicol. (Berl.) 32 (1974) 271.

4. AMERICAN INDUSTRIAL HYGIENE ASSOCIATION. Hygienic Guide Series, Nickel Carbonyl (NiCo4). Author, Cincinnati, Ohio 1968 (Revised).

5. ANDERSON, E. W., ANDELMAN, R. J., STRAUCH, J. M., FORTUIN, N. J. and KNELSON, J. H. Effect of low-level carbon monoxide exposure on onset and duration of angina pectoris: A study in ten patients with ischemic heart disease. Ann. intern. med. 79 (1973) 45.

6. ANDERSON, W. N., BROUGHTON, P M. G., DAWSON, J. B. and FISHER, G. W. An evaluation of some atomic absorption systems for the determination of lead in blood. Clin. chim. acta. 50 (1974) 129.

7. ANGERER, J., SZADKOWSKI, D. MANZ, A., PETT, R. and LEHNERT, G. Chronische Lösungsmittelbelastung am 
Arbeitsplatz: I. Gaschromatographische Bestimmung von Benzol und Toluol in der Luft und in Dampfraum von Blutproben. Int. Arch. Arbeitsmed. 31 (1973) 1.

8. ARONOW, W. S., HARRIS, C. N., ISBELL, IM. W., ROKAM, S. N. and IMPARATO, B. Effect of freeway travel on angina pectoris. Ann. intern. med. 77 (1972) 669.

9. ARTERBERRY, J. D., DURHAM, W. F., ELLIOT, J. W. and WOLFE, H. R. Exposure to parathion: Measurement by blood cholinesterase level and urinary p-nitrophenol excretion. Arch. environ. health, 3 (1961) 476.

10. ASKEVOLD, R. Routine analysis of porphyrin in urine. Scand. j. clin lab. invest. 3 (1951) 318.

11. ASTRAND, I., EHRNER-SAMUEL, H., KILBOM, $\AA$. and ÖVRUM, P. Toluene exposure: $\mathrm{I}$. Concentration in alveolar air and blood at rest and during exercise. Work-environ.-health 9 (1972) 119.

12. ASTRUP, P. Some physiological and pathological effects of moderate carbon monoxide. Brit. med. j. 4 (1972) 447.

13. AUGUSTINSSON, K. B. Analysis of biogenic amines and their related enzymes. In: D. Glich (ed.), Methods in biochemical unalysis. Intersciences Publishers, New York, N.Y. 1971, p. 217.

14. BAETJER, A. M., DAMRON, C. M. and BUDACZ, V. The distribution and retention of chromium in men and animals. Arch. ind. health 20 (1959) 136.

15. BAKIR, F., DAMLUJI, S. F., AMINZAKI, L., MURTADHA, M., KHALIDI, A., AL-RAWI, N.Y., TIHRITI, S., DHAKIR, H. I., CLARKSON, T. W., SMITH, J. C. and DOHERTY, R. A. Methylmercury poisoning in Iraq: An interuniversity report Science 181 (1973) 230.

16. BARBORIK, M. The problem of harmful exposures to chromium compounds. Ind. med. 39 (1970) 45.

17. BARDODEJ, $Z$. and BARDODEJOVA, $E$. The metabolism of ethylbenzene, styrene and alpha-methylstyrene. Proceedings of the $X V$ international congress on occupational health, Vienna Vol II-1 (1966) 457.

18. BARDODEJ, $Z$. and BARDODEJOVA, E. Biotransformation of ethylbenzene, styrene and alpha-methylstyrene in man. Am. ind. hyg. assoc. j. 31 (1970) 206.

19. BARETTA, E. D., STEWART, R. D. and MUTCHLER, J. E. Monitoring exposure to vinylchloride vapour: Breath analysis and continuous air sampling. $A m$. ind. hyg. assoc. j. 30 (1969) 537.

20. BARNES, J. R. and RANTA, K. E. The metabolism of dimethylformamide and dimethylacetamide. Toxicol. appl. pharmacol. 23 (1972) 271.

21. BARNES, J. R. and HENRY, N. W. III. The determination of $\mathrm{N}$-methylformamide and $\mathrm{N}$-methylacetamide in urine. $\mathrm{Am}$. ind. hyg. assoc. j. 35 (1974) 84

22. BARR, R. D., WOODGER, B. A. and REES, $P$. H. Levels of mercury in urine correlated with the use of skin lightening creams. Am. j. clin. pathol. 59 (1973) 36.

23. BASECQZ, J. M., LAUWERYS, R. and BUCHET, J. P. Etude comparative de divers tests biologiques d'exposition au plomb. Arch. mal. prof. med. tra. secur. soc. 32 (1971) 453.

24. BASIN, B. Le dosage de l'acide deltaaminolévulinique dans le saturnisme. Arch. mal. prof. med. tra. secur. soc. 24 (1963) 638.

25. BELL, Z. G., WOOD, M. W. and KURYLA L. A. Mercury exposure evaluations and their correlation with urine mercury excretions: 1. A method to determine mercury time-weighted average (TWA) exposures. J. occup. med. 15 (1973) 340.

26. BELL, Z. G., WOOD, M. W. and KURYLA, L. A. Mercury exposure evaluations and their correlation with urine mercury excretions: 2 Time-weighted average (TWA) exposures for mercury-chlorine cell employees. J. occup. med. 15 (1973) 420.

27. BELL, Z. G., LOVEJOY, H. B. and VIZENA, T. R. Mercury exposures evaluations and their correlation with urine mercury excretions: 3. Time-weighted average (TWA) mercury exposures and urine mercury levels. J. occup. med. 15 (1973) 501.

28. BERLIN, A., DEL CASTILHO, P. and SMEETS, J. European intercomparison programs. In: Proceedings of the international symposium environmental health, Amsterdam 1972. Commission of the European Communities, Luxembourg 1973 , p. 1033.

29. BERLIN, A., DEL CASTILHO, P. and SMEETS, J. Interlaboratory evaluation of proficiency testing in urinary $\delta$-aminolevulinic acid analyses. Clin. chem. 20 (1974) 749.

30. BERLIN, A and SCHALLER, K. H. European standardized method for the determination of $\delta$-aminolevulinic acid dehydratase activity in blood. Zeit. klin. chem. klin. biochem. 12 (1974) 389.

31. BERMAN, E. Determination of lead in blood. Am. j. clin. pathol. 36 (1961) 549.

32. BERTRAN-CAPELLA, A. Intoxication au Thallium. Masson et Cie, Paris 1972. $119 \mathrm{p}$.

33. BEST, E. M., Jr, and MURRAY, B. L. Observations on workers exposed to Sevin insecticide: A preliminary report. J. occup. med. 4 (1962) 507.

34. BLACKMORE, D. J. The determination of carbon monoxide in blood and tissue. Analyst. 95 (1970) 439.

35. BONSIGNORE, D., CALISSANO, P. and CARTASEGNA, C. Un semplice metodo per la determinazione della $\delta$-amino-levulinicodeidratasi nel sangue: Comportamento dell enzima nell intossicazione saturnina. Med. lav. 56 (1965) 199.

36. BOUDENE, IM. C. Estimation biologique de l'exposition aux hydrocarbures aliphatiques chlorés. Cah. notes documentaires (Paris) 59 (1970) 159. 
37. BOUDENE, C., GODIN, J. and ROUSSEL A. Méthode de dosage de l'oxyde de carbone dans le sang sans extraction séparée préalable, par absorption sélective dans l'infra-rouge. Arch. mal. prof. med. tra. secur. soc. 34 (1973) 449.

38. BRADWAY, D. E. and SHAFIK, T. M. Parathion exposure studies: A gas chromatographic method for the determination of low levels of p-nitrophenol in human and animal urine. Bull environ. contam. toxicol. 9 (1973) 134.

39. BROWN, V. H. K., HUNTER, C. G. and RICHARDSON, A. A blood test diagnostic exposure to aldrin and dieldrin. $B r . j$ ind. med. 21 (1964) 283.

40. BROWNE, R. C., ELLIS, R. W. and WEIGHTMAN, D. Inter-laboratory variation in measurement of blood-lead levels. Lancet II (1974) 1112.

41. BUCHET, J. P., LAUWERYS, R. and CAMBIER, M. An improved gas chromatographic method for the determination of phenol in urine. Eur. j. toxicol. 5 (1972) 27.

42. BUCHET, J. P. and LAUWERYS, R. Measurement of urinary hippuric and $\mathrm{m}$ methylhippuric acids by gas chromatography. Br. $j$. ind. med. 30 (1973) 125.

43. BUCHET, J. P., LAUWERYS, R. and ROELS, H. Le dosage par chromatographie en phase gazeuse des métabolites urinaires du trichloréthylène: l'acide trichloroacétique et le trichloroéthanol. Arch. mal. prof. med. tra. secur. soc. 35 (1974) 395.

44. BUCHET, J. P., LAUWERYS, R. and ROELS, H. Evaluation de l'exposition des travailleurs au styrène par le dosage de ses métabolites urinaires: les acides mandélique et phénylglyoxylique: I. Technique de dosage des métabolites par chromatographie en phase gazeuse. Arch. mal. prof. med. tra. secur. soc. 35 (1974) 511.

45. BUCHET, J. P., LAUWERYS, R. R. and ROELS, H. Comparison of three techniques for carboxyhaemoglobin determination. Int. Arch. Arbeitsmed. 33 (1974) 269.

46. BUCHWALD, $H$. The colorimetric determination of phenol in air and urine with a stabilized diazonium salt. Ann. occup. hyg. 9 (1967) 7.

47. BUTT, E. M., NUSBAUM, R. E., GLIMOUR, T. C., DIDIO, S. L. and MARIANOS. Trace metal levels in human serum and blood. Arch. environ. health 8 (1964) 52.

48. CAPELLINI, A. and ALESSIO, L. L'eliminazione urinaria di acido ippurico in operai esposti a toluolo. Med. lav. 62 (1971) 196

49. CASTELLINO, N. and ALOJ, S. Kinetics of the distribution and excretion of lead in the rat. $B r . j$. ind. med. 21 (1964) 308.

50. CERNIK, A. A. A drug ashing method for the determination of blood lead using cathode ray polarography. $B r . j$. ind. med. 24 (1967) 289

51. CERNIK, A. A. and SAYERS, IM. H. P.
Determination of lead in capillary blood using a paper punched disc atomic absorption technique. $B r . j$. ind. med. 28 (1971) 392

52. CHISOLM, J. J. Lead in red blood cells and plasma. J. pediatr. 84 (1974) 163.

53. CHOLAK, J. and HUBBARD, D. M. Determination of manganese in air and biological material. Am. ind. hyg. assoc. $j$. 21 (1960) 356.

54. CIKRT, M. Biliary excretion of ${ }^{203} \mathrm{Hg}$, ${ }^{64} \mathrm{Cu},{ }^{52} \mathrm{Mn}$ and ${ }^{210} \mathrm{~Pb}$ in the rat. $\mathrm{Br}$. $j$. ind. med. 29 (1972) 74.

55. COBURN, R. F., DANIELSON, G. K. BLACKMORE, W. S. and FORSTER, R. E. Carbon monoxide in blood: Analytical method and sources of error. J. appl. physiol. 19 (1964) 510.

56. COMMINS, B. T. and LAWTHER, P. J. A sensitive method for the determination of carboxyhaemoglobin in a finger prick sample of blood. Br. j. ind. med. 22 (1965) 139.

57. COMMISSION OF THE EUROPEAN COMMUNITIES. European colloquium: Problems of the contamination of man and his environment by mercury and cadmium. Author, Luxembourg July $3-5$, 1973. $691 \mathrm{p}$

58. COMMITTEE ON BIOLOGIC EFFECTS OF ATMOSPHERIC POLLUTANTS Fluorides. National Academy of Sciences, Washington, D.C. 1971. 295 p.

59. COMIMITTEE ON BIOLOGIC EFFECTS OF ATMOSPHERIC POLLUTANTS Chromium. National Academy of Sciences, Washington, D.C. 1974. 155 p.

60. COTZIAS, G. C. and GREENOUGH, J. J. The high specificity of the manganese pathway through the body. J. clin. invest. 37 (1958) 1298

61. CRAMER, K. and SELANDER, S. Studies in lead poisoning comparison between different laboratory tests. $B r . j$. ind. med. 22 (1965) 311.

62. CRANMER, M. F. Determination of pnitrophenol in human urine. Bull. environ. contam. toxicol. 5 (1970) 329.

63. CRANIMER, M. and FREAL, J. Gas chromatographic analysis of pentachlorophenol in human urine by formation of alkyl ethers. Life sci. 9 (1970) 121.

64. DALE, W. E., CURLEY, A. and HAYES W. J., Jr. Determination of chlorinated insecticides in human blood. Ind. med. surg. April (1967) 275.

65. DALE, W. E., MILES, J. W. and GAINES, T. B. Quantitative method for determination of DDT and DDT metabolites in blood serum. J. assoc. off. anal. chem. 53 (1970) 1287.

66. DAVIES, J. E., EDMUNSON, W. F., MACEO, A., BARQUET, A. and CASSADY, J. An epidemiologic application of the study of DDE levels in whole blood. Am. j. public. health 59 (1969) 435.

67. DAVIS, J. R. and ANDELMAN, S. L. Urinary delta-aminolaevulinic acid (ALA) levels in lead poisoning. Arch. environ. health 15 (1967) 53 .

68. DAVIS, M. H. and GROSSMAN, V. B. 
A sensitive method for determination of chromium in biological materials. Anal. biochem. 44 (1971) 339.

69. DAVIS, L. E., WANDS, J. R., WEISS, S. A., PRICE, D. L. and GIRLING, E. F. Central nervous system intoxication from mercurous chloride laxatives: Quantitative, histochemical and ultrastructural studies. Arch. neurol. 30 (1974) 428.

70. DAWSON, J. A., HEATH, D. F., ROSE, J. A., THAIN, E. M. and WARD, J. B. The excretion by humans of the phenol derived in vivo from 2-isopropoxyphenyl N-methylcarbamate. Bull WHO 30 (1964) 127.

71. DE BRUIN, A. and HOOLBOOM, H. Early signs of lead-exposure: A comparative study of laboratory tests. Br. j. ind. med. 24 (1967) 203

72. DE BRUIN, A. Effect of lead exposure on the level of $\delta$-aminolevulinic dehydratase activity. Med. lav. 59 (1968) 411.

73. DELVES, H. T. A micro-sampling method for the rapid determination of lead in blood by atomic-absorption spectrophotometry. Analyst 95 (1970) 431.

74. DENARDI, J. M., VAN ORDSTRAND, H. S., CURTIS, G. H. and ZIELINSKI, J. Berylliosis: Summary and survey of all clinical types observed in a twelve-year period. Arch. ind. hyg. occup. med. 8 (1953) 1.

75. Diagnosis of inorganic lead poisoning: A statement. Br. med. j. November (1968) 501.

76. DIVINCENZO, G. D., YANNO, F. J. and ASTILL, B. D. Human and canine exposures to methylene chloride vapor. $A m$. ind. hyg. assoc. j. 33 (1972) 125.

77. DJURIĆ, D., SURDUCKI, N. and BERKES, I. Iodine-azide test on urine of persons exposed to carbon disulphide. Br. j. ind. med. 22 (1965) 321.

78. DJURIC, D., POŚTIC-GRUJIN, A., GRAOVAC-LEPOSAVIC, L. and DELIC, V. Disulfiram as an indicator of human susceptibility to carbon disulfide. Arch. environ. health 26 (1973) 287.

79. DOCTER, H. J. and ZIELHUIS, R. L Phenol excretion as a measure of benzene exposure. Ann. occup. hyg. 10 (1967) 317.

80. DONATH, W. F. A simple portable apparatus for the semi-quantitative determination of the coproporphyrin content in urine. Arch. hig. rada toksikol. 7 (1956) 77.

81. DONOVAN, P. P. and FEELEY, D. T. A method for the determination of lead in blood by atomic absorption spectrophotometry. Analyst 94 (1969) 879.

82. DONOVAN, D. T., VOUGHT, V. M. and RAKOW, A. B. Laboratories which conduct lead analyses on biologic specimens. Arch. environ. health 23 (1971) 111.

83. DOSS, M., LOOK, D., HENNING, H., NAWROCK, P., SCHMIDT, A., DOLLE, W., KORB, G., LÜDERS, C. J. and STROHMEYER, G. Hepatic porphyrins and urinary porphyrins and porphyrin precursors in liver cirrhosis. Klin. Wschenschr, 50 (1972) 1025.
84. DURAN, M., KETTIN, D., DEBREE, P. K., VANDERHEIDEN, C. and WADMAN, S. K. Gas chromatographic analysis of urinary volatile phenols in patients with gastro-intestinal disordiers and normals. Clin. chim. acta 45 (1973) 341.

85. DURHAM, W. F., ARMSTRONG, J. F. and QUINBY, G. E. DDA excretion levels: Studies in persons with different degree of exposure to DDT. Arch. environ. health 11 (1965) 76.

86. DUTKIEWICZ, T. and TYRAS, H. A study of the skin absorption of ethylbenzene in man. $\mathrm{Br}$. j. ind. med. 24 (1967) 330.

87. DUTRA, F. R., CHOLAK, J. and HUBBARD, D. M. The value of beryllium determinations in the diagnosis of berylliosis. Am. j. clin. pathol. 19 (1949) 229.

88. EAGERS, R. Y. Toxic properties of inorganic fluorine compounds. Elsevier Publishing Company, Amsterdam 1969. $152 \mathrm{p}$.

89. EALY, J. A., BOLTON, N. E., MC ELHENG, R. J. and MORROW, R. W. Determination of lead in whole blood by graphite furnace atomic absorption spectrophotometry. Am. ind. hyg. assoc. $j$. 35 (1974) 566.

90. EDMUNDSON, W. F., DAVIES, J. E., NACHMAN, G. A. and ROETH, R. L. pp'-DDT and pp'-DDE in blood samples of occupationally exposed workers. Public health rep. 84 (1969) 53.

91. ELKINS, H. B. Analysis of biological materials as indices of exposure to organic solvents. Arch. ind. hyg. occup. med. 9 (1954) 212.

92. ELKINS, H. B. The chemistry of industrial toxicology. John Wiley \& Sons, Inc., New York, N. Y. 1959. 452 p.

93. ELKINS, H. B. Excretory and biologic threshold limits. Am. ind. hyg. assoc. $j$ 28 (1967) 305.

94. ELKINS, H. B., PAGNOTTO, L. D. and SMITH, H. L. Concentration adjustments in urinalysis. $A m$ ind. hyg. assoc. $j$. September (1974) 559.

95. ELLIOTT, J. W., WALKER, K. C., PENICK, A. E. and DURHAM, W. F. Insecticide exposure: A sensitive procedure for urinary p-nitrophenol determination as a measure of exposure to parathion. J. agric. food chem. 8 (1960) 111.

96. ENGSTROM, $K$. and RANTANEU, J. A new gas chromatographic method for determination of mandelic acid in urine. Int. Arch. Arbeitsmed. 33 (1974) 163.

97. ERTHE, T., HENSCHLER, D., MULLER, G. and SPASSOWSKI, M. Metabolism of trichloroethylene in man: I. The significance of trichloroethanol in long term exposure conditions. Arch. toxicol. (Berl.) 29 (1972) 171.

98. EUROPEAN COLLOQUIUM. Carbon monoxide environmental pollution and public health. Commission of European Communities, Luxembourg 1973. $437 \mathrm{p}$.

99. EVENSON, M. A. and PENDERGAST, D. D. Rapid ultromicro direct determination 
of erythrocyte lead concentration by atomic absorption spectrophotometry, with use of a graphite-tube furnace. Clin. chem. 20 (1974) 163.

100. FARELLY, R. O. and PYBUS, V. Measurements of lead in blood and urine by atomic "absorption spectrophotometry. Clin. chem. 15 (1969) 566.

101. FASSETT, D. W. Cyanides and nitriles. In: F. A. Patty (ed.). Industrial hygiene and toxicology (2nd edition). Interscience Publishers, New York, N.Y. 1963, p. 1991.

102. FELDMAN, F. J., KNOBLOCK, E. C and PURDY, W. C. The determination of chromium in biological material by atomic absorption spectroscopy. Anal. chim. acta 38 (1967) 489.

103. FERNANDEZ, F. J. and KAHN, H. L. The determination of lead in whole blood by atomic absorption spectrophotometry with the "Delves sampling cup" technique.. At. absorpt. newsl. 10 (1971) 1.

104. FLEMING, A. J. Industrial hygiene and medical control procedures: Manufacture and handling of organic lead compounds. Arch. environ. health 8 (1964) 266.

105. FOA, V., CAVAGNA, G. and MANFREDI, M. Valutazione della piomburia nella diagnosi di intossicazione da piombo tetraetile. Med. lav. 61 (1970) 491 .

106. FOURNIER, E., PETIT, L. and LECORSIER, A. Test à l'iodazide, indice de métabolisme des dérivés soufrés à la liaison CS. Eur. j. toxicol. 4 (1971) 337.

107. FRANT, R. and WESTENDORP, J. Medical control on exposure of industrial workers to trichloroethylene. Arch. ind. hyg. occup. med. 1 (1950) 308.

108. FRANZEN, E., POHLE, R. and KNOBLICK, K. Arbeitshygienische Untersuchungen in Betrieben Der Galvanotechnik: III Chrom im Urin. Z. Gesamte Hyg. 16 (1970) 657.

109. FRIBERG, L., PISCATOR, M. and NORDBERG, G. F. Cadmium in the environment (2nd ed.). Chemical Rubber Co., Cleveland, Ohio 1974. 248 p.

110. FRIEDMANN, F. A., GREENBERG, J. B., MERRILL, J. P. and DAMMIN, G. J. Consequences of ethylene glycol poisoning. Am. j. med. 32 (1962) 891.

111. FUNCKES, A. J., HAYES, W., Jr. and HARTWELL, W. V. Urinary excretion of paranitrophenol by volunteers following dermail exposure to parathion at different ambient temperatures. Agric. food chem. 11 (1963) 455.

112. GADJOS, A. L'intérêt du dosage de l'acide delta-aminolévulinique dans les urines pour le dépistage du saturnisme. Arch. mal. prof. med. tra. secur. soc. 25 (1964) 436.

113. GARRET, E. R. and LAMBERT, H. J Pharmacokinetics of trichloroethanol and metabolites and interconversions among variously referenced pharmacokinetic parameters. J. pharm. sci. 62 (1973) 550.

114. GAULTIER, M., FOURNIER, E., CERVAIS, P., MALKA, E. and EFTHYMIOU, M. M. Critères diagnostiques du saturnis- me dans une consultation de maladies professionnelles. Arch. mal. prof. med. tra. secur. soc. 34 (1973) 613.

115. GENTZ, J., JOHANSSON, S., LINDBLAD, B., LINDSTEDT, S. and ZETTERSTROM, R. Excretion of $\delta$-aminolevulinic acid hereditary tyrosinemia. Clin. chim acta 23 (1969) 257.

116. GIBSON, S. L. M., MACKENZIE, J. C. and GOLDBERG, A. The diagnosis of industrial lead poisoning. $B r . j$. ind. med. 25 (1968) 40.

117. GOBBI, A., SOVERINI, R. and GRISLER, R. Valori Normali di Metaemoglobinemia rilevati in 500 Abitanti di Milano. Med. lav. 65 (1974) 306.

118. GOLDWATER, L. J. Normal concentration of metals in urine and blood. WHO chron. 21 (1967) 191.

119. GOLDWATER, L. J. and HOOVER, A. W. An international study of "normal" levels of lead in blood and urine. Arch. environ. health 15 (1967) 60.

120. GOLDWATER, L. J. and JOSELOW, M. M. Absorption and excretion of mercury in man. Arch. environ. health 15 (1967) 327.

121. GÖTELL, P., AXELSON, O. and LINDELÖF, B. Field studies on human styrene exposure. Work-environ.-health 9 (1972) 76.

122. GRABECKI, J., HADUCH, T. and URBANOWICZ, H. Die einfachen Bestimmungsmethoden der $\delta$-aminolävulinsäure im Harn. Int. Arch. Gewerbepathol. Gewerbehyg. 23 (1967) 226.

123. GRAFFLAGE, B., BUTTGEREIT, G. KÜBLER, W. and MERTENS, H. M. Die Messung der Spurenelemente Chrom und Mangan im Serum mittels flammenIoser Atomabsorption. Z. Klin. Chem. Klin. Biochem. 12 (1974) 87.

124. GRANDJEAN, E., MUNCHINGER, R., TURRIAN, V., HAAS, P. A., KNOEPFEL, $H$. K. and ROSENMUND, $H$. Investigations into the effects of exposure to trichlorethylene in mechanical engineering. $B r . j$. ind. med. 12 (1955) 131.

125. GRIGGS, R. C. Lead poisoning: Hematologic aspects. Prog. hematol. 4 (1964) 117.

126. GRISLER, R. and FARINA, G. Validita clinica per la diagnosi di saturnismo di un nuovo indice ematologico: La concentrazione eritrocitaria media del plombo. Med. lav. 60 (1969) 360.

127. GRONKA, P. A., BOBKOSKIE, R. I., TOMCHICK, G. J., BACK, F. and RA$\mathrm{KOW}, \mathrm{A}$. B. Mercury vapor exposures in dental offices. J. am. dent. assoc. 81 (1970) 923.

128. HADJIMARKOS, D. M. Selenium in relation to dental caries. Food cosmet. toxicol. 11 (1973) 1083.

129. HAEGER, B. Urinary $\delta$-aminolevulinic acid and porphobilinogen in different types of porphyria. Lancet II (1958) 606.

130. HAEGER-ARONSEN, B. Studies on urinary excretion of delta-amniolaevulinic acid and other haem precursors in lead workers and lead intoxicated rabbits. 
Scand. j. clin. lab. invest. 12 (suppl. 47) (1960) 1.

131. HAEGER-ARONSEN, B. An assessment of the laboratory tests used to monitor the exposures of lead workers. $\mathrm{Br}$. j. ind. med. 28 (1971) 52.

132. HÄRKÖNEN, H., KALLIOKOSKI, P. and HIETALA, S. Styrene exposure in the plastic industry. In: Current research projects 1973. Institute of Occupational Health, Helsinki 1973, p. 13.

133. HASEGAWA, H., SATO, M. and KAKIZAKI, T. Metabolism of benzene: III. Sulfate conjugation of phenols produced from benzene. Ind. health 5 (1967) 41 .

134. HAYES, W. J., Jr. Studies on exposure during the use of anticholinesterase pesticides. Bull WHO 44 (1971) 277.

135. HENDERSON, R., SHOTWELL, H. P. and KRAUSE, L. A. Analyses for total, Lonic, and elemental mercury in urine as a basis for a biologic standard. $A m$. ind. hyg. assoc. j. 35 (1974) 576.

136. HERNBERG, S., NIKKANEN, J., MELLIN, G. and LILIUS, H. $\delta$-aminolevulinic acid dehydrase as a measure of lead exposure. Arch. environ. health 21 (1970) 140.

137. HERNBERG, S. and NIKKANEN, J. Effect of lead on $\delta$-aminolaevulinic acid dehydratase: A selective review. Proc. lek. 24 (1972) 77.

138. HERNBERG, S., TOLA, S., NIKKANEN, J. and VALKONEN, S. Erythrocyte $\delta$ aminolevulinic acid dehydratase in new lead exposure: A longitudinal study. Arch. environ. health 25 (1972) 109.

139. HESSEL, D. W. A simple and rapid quantitative determination of lead in blood. At. absorption newsl. 7 (1968) 55.

140. HILDERBRAND, D. C., KOIRTYOHANN, S. R. and PICKETT, E. E. The samplingboat technique for determination of lead in blood and urine by atomic absorption. Biochem med. 3 (1970) 437.

141. HILES, R. A. Absorption, distribution and excretion of inorganic tin in rats. Toxicol. appl. pharmacol. 27 (1974) 366.

142. HODGE, H. C. and SMITH, F. A. Air quality criteria for the effects of fluorides on man. J. air. pollut. control assoc. 20 (1970) 226.

143. HUNTER, C. G., ROBINSON, J. and JAGER, K. W. Aldrin and dieldrin: The safety of present exposures of the general population of the United Kingdom and the United States. Food cosmet. toxicol. 5 (1967) 781.

144. IFFLAND, R. and STICHT, G. Gaschromatographisches Verfahren zur bestimmung des Kuhlenmonoxidgehaltes im Blut. Arch. toxicol. (Berl.) 89 (1972) 325.

145. IKEDA, M. and OHTSUJI, H. Hippuric acid, phenol and trichloroacetic acid levels in the urine of Japanese subjects with no known exposure to organic solvents. $B r . j$. ind. med. 26 (1969) 162.

146. IKEDA, M. and OHTSUJI, H. Significance of urinary hippuric acid determination as an index of toluene exposure. Br. j. ind. med. 26 (1969) 244.
147. IKEDA, M., OHTSUJI, H., KAWAI, H. and KUNIYOSHI, M. Excretion kinetics of urinary metabolites in a patient addicted to trichloroethylene. $B r . j$. ind. med. 28 (1971) 203.

148. IKEDA, MI., OHTSUJI, H., IMAMURA, $\mathrm{T}$. and KOMOIKE, Y. Urinary excretion of total trichlorocompounds, trichloroethanol and trichlonoacetic acid as a measure of exposure to trichloroethylene and tetrachloroethylene. $B r . j$. ind. med. 29 (1972) 328.

149. IKEDA, M. and OHTSUJI, H. A comparative study of the excretion of Fujiwara reaction positive substances in urine of humans and rodents given trichloro or tetrachloro-derivatives of ethane and ethylene. Br. j. ind. med. 29 (1972) 99.

150. IKEDA, M., IMAMURA, T., HAYASHI, M., TABUCHI, T. and HARA, I. Evaluation of hippuric, phenylglyoxylic and mandelic acids in urine as indices of styrene exposure. Int. Arch. Arbeitsmed. 32 (1974) 93.

151. IMBUS, H. R., CHOLAK, J., MILLER, L. H. and STERLING, T. Boron, chromium, cadmium and nickel in blood and urine. Arch. environ. health 6 (1963) 286.

152. JAGER, K. W. Aldrin, dieldrin, endrin and telodrin: An epidemiological and toxicological study of long-term occupational exposure. Elsevier Publishing Company, Amsterdam 1970. 234 p.

153. JARAIZEWSKA, W. and JAKUBOWSKI, M. Preliminary evaluation of exposure to vanadium dust in chemical industry. Proceedings of the XIV international congress in occupational health, Madrid 1963.

154. JINDR̆ICHOVA, J. Anwendungsmöglichkeit der Manganbestimmung im Stuhl als Expositionstest. Int. Arch. Gewerbepath. Gewerbehyg. 25 (1969) 347.

155. JONDERKO, G., KUJAWSKA, A. and LANGAUER-LEWOWICKA, H. Problems of chronic manganese poisoning on the basis of investigations of workers at a manganese alloy foundry. Int. Arch. Arbeitsmed. 28 (1971) 250.

156. JOSELOW, M. M., GOLDWATER, L. J., ALVAREZ, A. and HERNDON, J. Absorption and excretion of mercury in man: XV Occupational exposure among dentists. Arch environ. health 17 (1968) 39

157. KALTREIDER, N. L., ELDER, M. J., CRALLEY, L. V. and CADWELL, M. O. Health survey of aluminium workers with special reference to fluoride exposure. J. occup. med, 14 (1972) 531.

158. KAZANTZIS, G., FLYNN, F. O., SPOWAGE, J. S. and TROTT, D. G. Renal tubular malfunction and pulmonary emphysema in cadmium pigment workers. Q. j. med. 32 (1963) 126.

159. KEENAN, R. G., BYERS, G. D. H., SALTZMAN, B. E. and HYSLOP, F. L. The "USPHS" method for determining lead in air in biological materials. $A m$. ind. hyg. assoc. j. 24 (1963) 481.

160. KEHOE, R. A. The metabolism of lead in man in health and disease; Lecture II. $J$. $r$. inst. public health hyg. 24 (1961) 101. 
161. KENT, N. L. and MC CHANCE, V. R. A. The absorption and excretion of minor elements in man; cobalt, nickel, tin and manganese. Biochem. j. 35 (1941) 877.

162. KEPPLER, J. F., MAXFIED, M. E., MOSS, W. D., TIETJEN, G. and LINCH, A. L. Interlaboratory evaluation of the reliability of blood lead analyses. $A m$. ind. hyg. assoc. j. 31 (1970) 412.

163. KIMIMERLE, G. and EBEN, A. Metabolism, excretion and toxicology of trichloroethylene after inhalation: 1. Experimental exposure on rats. Arch. toxicol. (Berl.) 30 (1973) 115.

164. KIMMERLE, G. and EBEN, A. Metabolism, excretion and toxicology of trichloroethylene after inhalation: 2. Experimental human exposure. Arch. toxicol. (Berl.) 30 (1973) 127.

165. KIMMERLE, G. and EBEN, A. Metabolism studies on N,N-Dimethylformamide: I. Studies in rats and dogs. Int. Arch. Arbeitsmed. 34 (1975) 109.

166. KIMMERLE, G. and EBEN, A. Metabolism studies of $\mathrm{N}, \mathrm{N}$-Dimethylformamide: II. Studies in persons. Int. Arch. Arbeitsmed. 34 (1975) 127.

167. KING, E. and THOMPSON, A. R. The measurement of lead absorption in industry. Ann. occup. hyg. 3 (1961) 247.

168. KINKAID, J. F., STANLEY, E. L., BECKWORTH, C. H. and SUNDERMAN, F. W. Procedure for detection prevention and treatment of nickel carbonyl exposure, including a method for the determination of nickel in biologic materials. Am. j. clin. pathol. 26 (1956) 107.

169. KJELDSEN, K., ASTRUP, P. and WANSTRUP, J. Ultrastructural intimal changes in the rabbit aorta after a moderate carbon monoxide exposure. Atherosclerosis 16 (1972) 67.

170. KJELLSTROM, T., TSUCHIYA, K., TOMPKINS, E., TAKABATAK, E., LIND, B. and LINNMAN, L. A comparison of methods for analysis of cadmium in food and biological material: A cooperative study between Sweden, Japan and U.S.A. In: Proceedings CEC-EPA-WHO international symposium - environment and health, Paris, 1974. Commission of the European Communities, Luxembourg. In press.

171. KLAASSEN, C. D. Biliary excretion of manganese in rats, rabbits and dogs. Toxicol appl. pharmacol. 29 (1974) 458.

172. KLEMPERER, F. W., MARTIN, A. P. and VAN RIPER, J. Beryllium excretion in humans Arch, ind. hyg. occup. med. 4 (1951) 251.

173. KOLMODIN-HEDMAN, B. Exposure to lindane and DDT and its effects on drug metabolism and serum lipoproteins. Noristedt \& Söner, Stockholm 1974. 48 p.

174. KOPITO, L., BYERS, R. K. and SCHWACKMAN, $H$. Lead in hair of children with chronic lead poisoning. New eng. j. med. 276 (1967) 949.

175. KUBASIK, N. P., VOLOSIN, M. T. and MURRAY, M. H. A quantitative micro technique for the analysis of lead in blood by carbon rod atomization and atomic absorption spectrophotometry. Clin. biochem. 20 (1974) 300.

176. LAHAM, S. Metabolism of industrial solvents. Ind. med. 39 (1970) 61 .

177. LAHAM, $\mathrm{S}$. and MATUTINA, E. O. Microdetermination of mesitylenic acid in human urine. Arch. toxicol. (Berl.) 30 (1973) 199.

178. LAMBERT, J. L., TSCHORN, R. R. and HAMLIN, P. A. Determination of carbon monoxide in blood Anal. chem. 44 (1972) 1529.

179. LAMOLA, A. A. and YAMANE, T. Zinc protoporphyrin in the erythrocytes of patients with lead intoxication and iron deficiency anemia. Science 186 (1974) 936.

180. LAMOLA, A., FOSELOW, M. and YAMANE, T. Zinc protoporphyrin (ZPP): A simple, sensitive, fluorometric screening test for lead poisoning. Clin chem. 21 (1975) 93.

181. LAUWERYS, R. Précis de toxicologie industrielle et des intoxications professionnelles. Editions Duculot, Gembloux 1972. $609 \mathrm{p}$.

182. LAUWERYS, R. Le diagnostic biologique d'exposition excessive au plomb. Louvain méd. 91 (1972) 19.

183. LAUWERYS, R., DELBROECK, R. and VENS, M. Automated analysis of deltaaminolaevulinic acid in urine. Clin. chim. acta 40 (1972) 443.

184. LAUWERYS, R., BUCHET, J. P, and ROELS, H. A. Comparative study of effect of inorganic lead and cadmium on blood $\delta$-aminolevulinate dehydratase in man. Br. j. ind. med. 30 (1973) 359.

185. LAUWERYS, R., BUCHET, J. P. and ROELS, H. Contrôle biologique de l'exposition à quelques solvants industriels. Louvain méd. 92 (1973) 1.

186. LAUWERYS, R. and BUCHET, J. P. Occupational exposure to mercury vapors and biological action. Arch. environ. health. 27 (1973) 65.

187. LAUWERYS, R., BUCHET, J. P. and ROELS, H. Dosage du cadmium et du plomb dans le sang et les urines par spectrophotométrie d'absorption atomique précédée d'une chromatographie sur résine échangeuse d'ions. In: Problems of the contamination of man and his environment by mercury and cadmium. Commission of the European Communities, Luxembourg 1973, p. 231.

188. LAUWERYS, R., BUCHET, J. P. and ROELS, H. Effets subcliniques de l'exposition humaine au cadmium. In: Problems of the contamination of man and his environment by mercury and cadmium. Commission of the European Communities, Luxembourg 1973, p. 447.

189. LAUWERYS, R., BUCHET, J. P., ROELS, H., BROUWERS, J. and STANESCU, D. Epidemiological survey of workers exposed to cadmium: Effect on lung, kidney and several biological indices. Arch. environ. health 28 (1974) 145.

190. LAUWERYS, R., BUCHET, J. P. and ROELS, H. Les effets toxiques d'une 
exposition modérée au monoxyde de carbone: Un risque souvent ignoré. Louvain méd 93 (1974) 231.

191. LAUWERYS, R., BUCHET, J. P., ROELS, H. A. and MATERNE, D. Relationship between urine $\delta$-aminolevulinic acid excretion and the inhibition of red cell $\delta$-aminolevulinate dehydratase by lead. Clin. toxicol. 7 (1974) 383 .

192. LAUWERYS, R., BUCHET, J. P., ROELS, H., BERLIN, A. and SMEETS, J. Intercomparison program of lead mercury and cadmium analysis in blood, urine and aqueous solutions. Clin. chem. 27 (1975) 551.

193. LAWS, F. R., CURLEY, A. and BIROS, F. J. Men with intensive occupational exposure to DDT. Arch. environ. health 15 (1967) 766.

194. LEAF, G. and ZATMAN, L. J. A study of the conditions under which methanol may exert a toxic hazard in industry. Br. j. ind. med. 9 (1952) 19.

195. LEBBE, J., LAFARGE, J. P. and MENARD, R. A. Recherche et dosage des monophénols urinaires par chromatographie en phase gazeuse. Arch. mal. prof. med. tra. secur. soc. 27 (1966) 565.

196. LEHNERT, G., SCHALLER, K. H. and HAAS, T. Atomabsorptionsspektrometrische Cadmiumbestimmung in Serum und Harn. Z. Klin. Chem. 6 (1968) 174.

197. LEHNERT, G., SCHALLER, K. H. and SZADKOWSKI, D. Eine zuverlässige Schnellmethode zur Bleibestimmung in kleinen Blutmengen. Z. Klin. Chem. Klin Biochem. 7 (1969) 310.

198. LEHNERT, G., SZADKOWSKI, D. and WOITOWITZ, $H$. J. Inadequacies of the red cell profile in the health supervision of lead workers. Clin toxicol. 2 (1969) 249.

199. LEHNERT, G., KLAVIS, G., SCHALLER, $K$. $H$. and HAAS, T. Cadmium determination in urine by atomic absorption spectrometry as a screening test in industrial medicine. $\mathrm{Br}$. j. ind. med. 26 (1969) 156.

200. LEIBMAN, K. C. and MC ALLISTER, W. J., Jr. Metabolism of trichloroethylene in liver microsomes: III. Induction of the enzymic activity and its effect on excretion of metabolites. J. pharmacol exp. ther. 157 (1967) 574.

201. LEWIS, C. E. The biological effects of vanadium: II. The signs and symptoms of occupational vanadium exposure. Arch. ind. health 19 (1959) 497.

202. LI, R. T. and HERCULES, D. M. Determination of chromium in biological samples using chemiluminescence. Anal. chem. 46 (1974) 916.

203. LICHTMAN, H. C. and FELDMAN, F. In vitro pyrrole and porphyrin synthesis on lead poisoning and iron deficiency. $J$. clin. invest. 42 (1963) 830.

204. MAGOS, L., TUFFERY, A. A. and CLARKSON, T. W. Volatilisation of mercury by bacteria. $B r . j$. ind. med. 21 (1964) 294.

205. MAGOS, L. Relevancy of bivalent sulphur excretion to carbon disulphide exposure in different metabolic conditions. $B r . j$. ind. med. 29 (1972) 90.

206. MAHONEY, J. P. and SMALL, W. J. Studies on manganese: III. The biological half-life of radiomanganese in man and factors which affect this half-life. $J$. clin. invest. 47 (1968) 643.

207. MAHONEY, J. P., SARGENT, K., GRELAND, M. and SMALL, W. Studies on manganese: I. Determination in serum by atomic absorption spectrophotometry. Clin. chem. 15 (1969) 312.

208. MALCOLM, D. Industrial control of personnel. Ann. occup. hyg. 8 (1965) 35.

209. MARZULLI, F. N. and BROWN, D. W. Potential systemic hazards of topically applied mercurials. J. soc. cosmet. chem. 23 (1972) 875.

210. MATERNE, D., LAUWERYS, $\mathbf{R}$ BUCHET, J. P., ROELS, H., BROUWERS, J. and STANESCU, D. Investigations sur les risques résultant de l'exposition au cadmium dans deux entreprises de production et deux entreprises d'utilisation du cadmium. Cah. méd. trav. 12 (1975) 1

211. MATHOT, J. Biologie appliquée à la médecine du travail: Estimation biologique du saturnisme. Arch. mal. prof. med. tra. secur. soc. 34 (1973) 538.

212. MAUZERALL, D. and GRANICK, S. The occurence and determination of $\delta$-aminolaevulinic acid and porphobilinogen in urine. J. biol. chem. 219 (1956) 435.

213. MC CHESNEY, E. W., GOLDBERG, L. PAREKH, C. K., RUSSEL, J. C. and MIN, B. H. Reappraisal of the toxicology of ethyleneglycol: II. Metabolism studies in laboratory animals. Food cosmet. toxicol. 9 (1971) 21.

214. MC NEELY, M. D., NECHAY, M. W. and SUNDERMAN, F. W., Jr. Measurements of nickel in serum and urine as indices of environmental exposure to nickel. Clin. chem. 18 (1972) 992.

215. MICHAUX, P., BOITEAU, H. L. and TOLOT, F. Valeur et limite du dépistage clinique et biologique en pathologie professionnelle. Arch. mal. prof. med. tra. secur. soc. 32 (1971) 1.

216. MILBY, T. H., SAMULES, A. J. and OTTOBONI, F. J. Human exposure to lindane: Blood lindane levels as a function of exposure. $J$ : occup. med. 10 (1968) 584.

217. MILLAR, J. A., THOMPSON, G. G. GOLDBERG, A., BARRY, P. S. I. and LOWE, E. H. $\delta$-aminolevulinic acid dehydratase activity in the blood of men working with lead alkyls. $\mathrm{Br}$. $j$. ind. med. 29 (1972) 317.

218. MONTGOMERY, M. R. and RUBIN, R. J. The effect of carbon monoxide inhalation on in vivo drug metabolism in the rat. $J$. pharmacol. exp. ther. 179 (1971) 465.

219. MOORE, M. R., BEATTIE, A. D., THOMPSON, G. G. and GOLDBERG, A. Depression of $\delta$-aminolaevulinic acid dehydratase activity by ethanol in man and rat. Clin. sci. 40 (1971) 81

220. MORGAN, J. G. A simplified method for 
the estimation of nickel in urine. $B r, j$. ind. med. 17 (1960) 209.

221. MOUNTAIN, J. T., STOCKELL, F. R., Jr. and STOKINGER, H. E. Studies in vanadium toxicology: III. Fingernail cystine as an early indicator of metabolic changes in vanadium workers. Arch. ind. health 12 (1955) 494.

222. MƯLLER, G., SPASSORSKI, M. and HENSCHLER, D. Trichlorethylene exposure and trichloroethylene metabolites in urine and blood. Arch. toxicol. (Berl.) 29 (1972) 335.

223. NABB, D. P., STEIN, W. J. and HAYES, W., Jr. Rate of skin absorption of parathion and paraoxon. Arch. environ. health 12 (1966) 501.

224. NACHMAN, G. A., FREAL, J. J., BARQUET, A. and MORGADE, C. A simplified method for analysis of DDT and DDE in blood for epidemiologic purposes. Health lab. sci. 6 (1969) 148.

225. NATIONAL INSTITUTE FOR OCCUPATIONAL SAFETY AND HEALTH. Criteria for a recommended standard: Occupational exposure to carbon monoxide. U.S. Department of Health, Education and Welfare, Washington, D.C. 1972. $\mathrm{I}-\mathrm{XI}$.

226. NATIONAL INSTITUTE FOR OCCUPATIONAL SAFETY AND HEALTH. Criteria for a recommended standard: Occupational exposure to inorganic arsenic. U.S. Department of Health, Education and Welfare, Washington, D.C. 1973.105 p.

227. NATIONAL INSTITUTE FOR OCCUPATIONAL SAFETY AND HEALTH. Criteria for a recommended standard: Occupational exposure to toluene. U.S. Department of Health, Education and Welfare, Washington, D.C. 1973. 98 p.

228. NATIONAL INSTITUTE FOR OCCUPATIONAL SAFETY AND HEALTH. Criteria for a recommended standard: Occupational exposure to benzene. U.S. Department of Health, Education and Welfare, Washington, D.C. $1974.137 \mathrm{p}$.

229. NEEFUS, J. D., CHOLAK, J. and SALTZMAN, B. E. The determination of fluoride in urine using a fluoride specific ion electrode. Am. ind. hyg. assoc. j. 31 (1970) 96.

230. NITTER-HAUGE, S. Poisoning with ethylene glycol monomethyl ether. Acta med. scand. 188 (1970) 277.

231. NOMIYAMA, $K$. Estimation of trichloroethylene exposure by biological materials. Int. Arch. Arbeitsmed. 27 (1971) 281.

232. NOMIYAMA, $\mathrm{K}$. and NOMIYAMA, $\mathrm{H}$. Metabolism of trichloroethylene on human: Sex difference in urinary excretion of trichloroacetic acid and trichloroethanol Int. Arch. Arbeitsmed. 28 (1971) 37.

233. NOMIYAMA, $\mathrm{K}$. and NOMIYAMA, $\mathrm{H}$. Respiratory retention, uptake and excretion of organic solvents in man. Int. Arch. Arbeitsmed. 32 (1974) 75.

234. NOMIYAMA, $K$. and NOMIYAMA, $H$. Respiratory elimination of organic solvents in man. Int. Arch. Arbeitsmed. 32 (1974) 85 .
235. NOMOTO, S. and SUNDERMAN, F. W., $\mathrm{Jr}$. Atomic absorption spectometry of nickel in serum, urine and other biological materials. Clin. chem. 16 (1970) 477.

236. NORVAL, E. and BUTLER, L. R. P. The determination of lead in blood by atomic absorption with the high-temperature graphite tube. Anal. chim. acta 58 (1972) 47.

237. OGATA, M., TOMOKUNI, $K$. and TAKATSUKA, Y. Quantitative determination in urine of hippuric acid and $m$ - or $p-$ methylhippuric acid metabolites of toluene and $\mathrm{m}$ - or $\mathrm{p}$-xylene. Br. j. ind. med. 26 (1969) 330.

238. OGATA, M., TOMOKUNI, $K$. and TAKATSUKA, Y. Urinary excretion of hippuric acid and $m$ or $p$ methylhippuric acid in the urine of persons exposed to vapours of toluene and $\mathrm{m}$ - or $\mathrm{p}$-xylene as a test of exposure. Br. j. ind. med. 27 (1970) 43.

239. OGATA, M., TAKATSUKA, Y. and TOMOKUNI, K. Excretion of organic chlorine compounds in the urine of persons exposed to vapours of trichloroethylene and tetrachloroethylene. $B r . j$. ind. med. 28 (1971) 386.

240. OGATA, M. and SAEKI, T. Measurement of chloral hydrate, trichloroethanol, trichloroacetic acid and monochloroacetic acid in the serum and the urine by gas chromatography: Int. Arch. Arbeitsmed. 33 (1974) 49.

241. OHTSUJI, $H$. and IKEDA, M. A rapid colorimetric method for the determination of phenylglyoxylic and mandelic acids: Its application to the urinalysis of workers to styrene vapour. $B r . j$. ind. med. 27 (1970) 150.

242. OHTSUJI, $H$. and IKEDA, M. Quantitative relationship between atmospheric phenol vapour and phenol in the urine of workers in Bakelite factories. $\mathrm{Br} . j$. ind. med. 29 (1972) 70.

243. OLTRAMARE, M., DESBAUMES, E. IMHOFF, C. and MICHIELS, W. Toxicologie du styrène monomère: Recherches expérimentales et cliniques chez l'homme. Editions Médecine et Hygiène, Genève 1974. $100 \mathrm{p}$.

244. ORNOSKY, M. Coproporphyrinuria and urine-lead findings: Fifteen years of experience. Am. ind. hyg. assoc. j. 29 (1968) 228.

245. PAGNOTTO, L. D., ELKINS, H. B., BRUGSCH, H. G. and WALKLEY, J. F. Industrial benzene exposure from petroleum naphta. Am. ind. hyg. assoc. j. 22 (1961) 417.

246. PAGNOTTO, L. D. and LIEBERMAN, L. M. Urinary hippuric acid excretion as an index of toluene exposure. Am. ind. hyg. assoc. j. 28 (1967) 129.

247. PALMER, L. and KOLMODIN-HEDMAN, B. Improved quantitative gas chromatographic method for the analysis of small amounts of chlorinated hydrocarbon pesticides in human plasma. $J$. chromatogr. 74 (1972) 21.

248. PARKE, D. V. and WILLIAMS, R. T. Studies in detoxication: The metabolism of 
benzene (a); the determination of benzene (b); the elimination of unchanged benzene in rabbits. Biochem. j. 46 (1953) 236.

249. PARKES, D. V. and WILLIAMS, R. T. The metabolism of benzene containing ${ }^{14}$ C-benzene. Biochem. j. 54 (1953) 231.

250. PATTY, F. A. Arsenic, phosphorus, selenium, sulfur and tellurium. In: F. A. Patty (ed.), Industrial hygiene and toxicology (vol. II). Initerscience Publishers, New York, N.Y. 1963, p. 871.

251. PEKAREK, R. S., HAUER, E. C., WANNEMACHER, R. W., Jr. and BEISEL, W. $R$. The direct determination of serum chromium by an atomic absorption spectophotometer with a heated graphite atomizer. Anal. chem. 59 (1974) 283.

252. PENALVER, $R$. Diagnosis and treatment of manganese intoxication. Arch. ind. health 16 (1957) 64.

253. PERGAL, M., VUKOJEVIC, N., CIRINPOPOV, N., SAD, N., DJURIC, D. and BOJOVIC, T. Carbon disulfide metabolites excreted in the urine of exposed workers: I. Isolation and identification of 2-mercapto-2-thiazolinone-5. Arch. environ. health 25 (1972) 38.

254. PERGAL, M., VUKOJEVIC, N., SAD, N. and DJURIC, D. II. Isolation and identification of thiocarbamide. Arch. environ. health 25 (1972) 42.

255. PERRET, J. La recherche de l'acide trichloroacétique dans les urines des sujets exposés au trichloréthylène. Arch. mal. prof. med. tra. secur. soc. 24 (1963) 676.

256. PERRY, H. M., Jr. and PERRY, E. F. Normal concentrations of some trace metals in human urine: Changes produced by ethylenediamine tetraacetate. $J$. clin. invest. 38 (1959) 1452.

257. PETTIGREW, A. R. and FELL, G. S. Simplified colorimetric determination of thiocyanate in biological fluids and its applicaltion to investigation of the toxic amblyopias. Clin. chem. 18 (1972) 996.

258. PFÄFFLI, P. and BACKMAN, A.-L. Trichloroethylene concentrations in blood and expired air as indicators of occupational exposure: A preliminary report. Work-environ.-health 9 (1972) 140.

259. PHILIPPE, R., LAUWERYS, R., BUCHET, $J$. P. and ROELS, $H$. Evaluation de l'exposition des travailleurs au styrène par le dosage de ses métabolites urinaires: 2. Applications aux travailleurs fabriquant des polyesters. Arch. mal. prof. med. tra. secur. soc. 35 (1974) 631.

260. PINTO, S. S. and MC GILL, C. M. Arsenic trioxide exposure in industry. Ind. med. surg 22 (1953) 281.

261. PIOTROWSKI, J. Further investigations on the evaluation of exposure to nitrobenzene. $B r . j$. ind. med. 24 (1967) 60.

262. PIOTROWSKI, J. K. Evaluation of exposure to phenol: Absorption of phenol vapour in the lungs and through the skin and excretion of phenol in urine. $\mathrm{Br}, j$. ind. med. 28 (1971) 172.

263. PORTEOUS, J. W. and WILLIAMS, R. T.
Studies in detoxication: The metabolism of benzene. Biochem. j. 44 (1949) 46.

264. RAINSFORD, S. G. and LLOYD DAVIES, T. A. Urinary excretion of phenol by men exposed to vapour of benzene: A screening test. Br. j. ind. med. 22 (1965) 21.

265. RENSHAW, G. D., POUNDS, C. A. and PEARSON, E. F. Variation in lead concentration along single hairs as measured by non-flame atomic absorption spectrophotometry. Nature 238 (1972) 162.

266. RENTOS, P. G. and SELIGMAN, E. J. Relationship between environmental exposure to mercury and clinical observation. Arch. environ. health 16 (1968) 794.

267. REPORT OF AN INTERNATIONAL COMMITTEE. Maximum allowable concentration of mercury compounds. Arch. environ. health 19 (1969) 891.

268. RILEY, E. C., FASSETT, B. W. and SUTTON, W. L. Methylene chloride vapor in expired air of human subjects. Am. ind. hyg. assoc. j. 27 (1966) 341.

269. RIVERS, J. B. Gas chromatographic determination of pentachlorophenol in human blood and urine. Bull. environ. contam. toxicol. 8 (1972) 294.

270. ROAN, C. C., MORGAN, D. P., COOK, N. and PASCHAL, E. H. Blood cholinesterases, serum parathion concentrations and urine p-nitrophenol concentrations in exposed individuals. Bull. environ. contam. toxicol. 4 (1969) 362.

271. ROBINSON, J. The pharmacodynamics of dieldrin. VIth international congress of plant protection, Vienna 1917.

272. ROELS, H., LAUWERYS, R., BUCHET, J. P., BERLIN, A. and. SMEETS, J. Comparison of four methods for determination of $\delta$-aminolevulinic acid in urine and evaluation of critical factors. Clin. chem. 20 (1974) 753.

273. ROELS, H., BUCHET, J. P. and LAUWERYS, R. Inhibition of human erythrocyte $\delta$-aminolevulinate dehydratase by lead: In vitro artifact or real phenomenon in vivo? Int. Arch. Arbeitsmed. 33 (1974) 277.

274. ROELS, H. LAUWERYS, R., BUCHET, J. P. and MATERNE, D. Study on cadmium proteinuria: Glomerular dysfunction: An early sign of renal impairment. In: Proceedings $\mathrm{CEC}-\mathrm{EPA}-\mathrm{WHO}$ international symposium environment and health, Paris, June 1974. Commission of the European Communities, Luxembourg. In press.

275. ROELS, H. A., LAUWERYS, R. R., BUCHET, J. P. and VRELUST, M. T. Response of free erythrocyte porphyrin and urinary $\delta$-aminolevulinic acid in men and women moderately exposed to lead. Int. Arch. Arbeitsmed. 34 (1975) 97.

276. ROELS, H. A., BUCHET, J. P., LAUWERYS, R., HUBERMONT, G., BRUAUX, P., CLAEYS-THOREAU, F., LAFONTAINE, A. and VAN OVERSCHELDE, J. Impact of air pollution by lead on the haem biosynthetic pathway in school-age children. Arch. environ. health. In press. 277. ROSEN, J. F. The microdetermination of 
blood lead in children by flameless atomic absorption: The carbon rod atomizer. $J$. lab. clin. med. 80 (1972) 567.

278. SAITA, G. and MOREA, L. La determinazione dell acido deltaaminolevulinico sierico ed urinario ai fini della diagnosi di pregressa intossicazione de blombo. Med. lav. 55 (1964) 357.

279. SALVINI, M., BINASCHI, S. and RIVA, M. Evaluation of the psychological functions in humans exposed to trichloroethylene. Br. j. ind. med. 28 (1971) 293.

280. SASSA, S., GRANICK, J. L., GRANICK, S., KAPPAS, A. and LEVERE, R. D. Studies in lead poisoning: I. Microanalysis of erythrocyte protoporphyrin levels by spectrophotometry in the detection of chronic lead intoxication in the subclinical range. Biochem. med. 8 (1973) 135.

281. SATO, M. and HASEGAWA, H.: Metabolism of benzene: I. Extraction of benzene hydroxylating enzymes. Ind. health 5 (1967) 24.

282. SATO, M., KAKIZAKI, T. and HASEGAWA, H. Metabolism of benzene: II. Hydroxylation of benzene by enzymes extracted from rabbit liver. Ind. health 5 (1967) 29.

283. SCHALLER, K. H., KUHNER, A. and LEHNERT, G. Nickel als Spurenelement im menshlichen Blut. Blut 17 (1968) 155.

284. SCHROEDER, H. A., BALASSA, J. J. and TIPTON, I. H. Abnormal trace elements in man: Tin $J$. chronic dis. 17 (1964) 483.

285. SCHWARTZ, S., ZIEVE, L. and WATSON, C. J. An improved method for the determination of urinary coproporphyrin and an evaluation of factors influencing the analysis. J. lab. clin. med. 37 (1951) 843.

286. SEARLE, B., CHAN, W. and DAVIDOW, B. Determination of lead in blood and urine by anodic stripping voltametry. Clin. chem. 19 (1973) 76.

287. SEKI, Y., URASHINA, X., AIKAWA, H., MATSUMURA, H., ICHIKAWA, Y., HIRATSUKA, F., YOSHIOKA, Y., SHIMBO, S. and IKEDA, M. Trichloro-compounds in the urine of humans exposed to methyl chloroform at sub-threshold levels. Int. Arch. Arbeitsmed. 34 (1975) 39.

288. SELANDER, S. and CRAMER, K. Determination of lead in blood by atomic absorption spectrophotometry. $B r . j$. ind. med. 25 (1968) 209.

289. SELANDER, S. and CRAMER, K. Interrelationships between lead in blood, lead in urine, and ALA in urine during lead work. B. j. ind. med. 27 (1970) 28.

290. SENHAUSER, D. A. Minuteman disease: Lead poisoning. Arch. environ. health 10 (1965) 801.

291. SHAFIK, M. T., SULLIVAN, H. C. and ENOS, H. F. A method for the determination of 1 naphtol in urine. Bull environ. contam. toxicol. 6 (1971) 34 .

292. SHAFIK, T., BRADWAY, D. E., ENOS, H. F. and YOBS, A. R. Human exposure to organophosphorus pesticides: A modified procedure for the gas-liquid chromato- graphic analysis of alkyl phosphate metabolites in urine. Agric. food chem. 21 (1973) 625.

293. SHERWOOD, R. J. and CARTER, F. W. G. The measurement of occupational exposure to benzene vapour. Ann. occup. hyg. 13 (1970) 125.

294. SIGGAARD-ANDERSEN, O., NØRGAARD-PEDERSEN, B. and REM, J. Hemoglobin pigments: Spectrophotometric determination of oxy-, carboxy-, met- and sulfhemoglobin in capillary blood. Clin. chim. acta 42 (1972) 85.

295. SJÖBERG, S. G. and RIGNER, K. G. Skin, eye, and respiratory tract symptoms associated with cleaning of oil-fired boilers, an investigation with special reference to vanadium in blood and urine. Nord. hyg. tidskr. 37 (1956) 217. (only summary in English)

296. SKERFVING, S. Mercury in fish - Some toxicological considerations. Food cosmet. toxicol. 10 (1972) 545.

297. SMALL, K. A., RADFORD, E. P., FRAZIER, J. M., RODKEY, F. L. and COLLISON, H. A. A rapid method for simultaneous measurements of carboxy and methemoglobin in blood. J. appl. physiol. 31 (1971) 154.

298. SMITH, R. G., VORWALD, A. J., PATIL, L. S. and MOONEY, T. F., Jr. Effects of exposure to mercury in the manufacture of chlorine. Am. ind. hyg. assoc. j. 31 (1970) 687.

299. SNYDER, R., UZUKI, F., GONOSUN, L., BROMFELD, E. and WELLS, A. The metabolism of benzene in vitro. Toxicol. appl. pharmacol. 11 (1967) 346.

300. STANKOVIC, M. K. Biochemical tests for the appraisal of exposure to lead. Arch. environ. health 23 (1971) 265.

301. STERNER, J. H. and LIDFELDT, V. The selenium content of "normal" urine. $J$. pharmacol, exp. ther. 73 (1941) 205.

302. STEWART, R. D., ARBOR, A., GAY, H. H., ERLEY, D. S., HAKE, C. L. and PETERSON, J. E. Human exposure to carbon tetrachloride vapor. J. occup. med. 3 (1961) 586.

303. STEWART, R. D., GAY, H. H., ERLEY, D. S., HAKE, C. L. and SCHAFFER, A. W. Human exposure to 1,1,1-trichloroethane vapor: Relationship of expired air and blood concentrations to exposure and toxicity. Am. ind. hyg. assoc. j. 22 (1961) 252.

304. STEWART, R. D., ARBOR, A., GAY, H. H., ERLEY, D. S., HAKE, C. L. and SCHAFFER, A. W. Human exposure to tetrachloroethylene vapor. Arch. environ. health 2 (1961) 516.

305. STEWART, R. D. and ROWE, V. K. Quinze ans d'étude sur le 1,1,1-trichloroethane. Arch. mal. prof. med. tra. secur. sec. 28 (1967) 194.

306. STEWART, R. D., DODD, H. C., BARETTA, E. D., SCHAFFER, A. W. and MUTCHLER, J. E. Chronic overexposure to benzene vapor. Toxicol. appl. pharmacol. 10 (1967) 381.

307. STEWART, R. D., DODD, H. C., BA- 
RETTA, E. D. and SCHAFFER, A. W. Human exposure to styrene vapor. Arch. environ. health 16 (1968) 656.

308. STEWART, R. D., GAY, H. H., SCHAFFER, A. W., ERLEY, D. S. and ROWE, V. K. Experimental human exposure to methyl chloroform vapor. Arch. environ. health 19 (1969) 467.

309. STEWART, R. D., DODD, H. C., GAY, H. H. and ERLEY, D. S. Experimental human exposure to trichloroethylene. Arch. environ. health 20 (1970) 64.

310. STEWART, R. D., BARETTA, E. D., DODD, H. C. and TORKELSON, T. T. Experimental human exposure to tetrachloroethylene. Arch. environ. health 20 (1970) 224.

311. STEWART, R. D., FISHER, T. N., HOSKO, M. J., PETERSON, J. E., BARETTA, E. D. and DODD, H. C. Carboxyhemoglobin elevation after exposure to dichloromethane. Science 176 (1972) 295.

312. STEWART, R. D., FISHER, T. N., HOSKA, H. J., PETERSON, J. E., BARETTA, E. D. and DODD, H. C. Experimental human exposure to methylene chloride. Arch. environ. health 25 (1972) 342.

313. STEWART, R. D., HAKE, C. L., LEBRUN, A. J., PETERSON, J. E., FORSTER, H. V., HOSKO, M. J., NEWTON, P. E., SOTO, R. J., DODD, H. C., GRAFF, S. A., DONOHOO, K. K. and MELLENDER, J. W. Biologic standards for the industrial worker by breath analysis: Trichloroethylene. [HEW publications (NIOSH) no. 74-133]. U.S. Department of Health Education and Welfare, Washington, D.C. July 1974.

314. STRETZ, P. E. and STAHR, H. M. Determination on chlorinated pesticides in whole blood. J. assoc. of anal. chem. 56 (1973) 1173.

315. STUIK, E. J. Biological response of male and female volunteers to inorganic lead. Int Arch. Arbeitsmed. 33 (1974) 83

316. STUIK, E. J. and ZIELHUIS, R. L. Increased susceptibility of females to inorganic lead. Communication no. 57 presented at the International Symposium on Recent Advances in the Assessment of the Health Effects of Environmental Pollution, organized jointly by CEC-EPA-WHO, Paris, June 24-28, 1974.

317. SUBCOMMITTEE OF THE HYGIENE STANDARDS COMMITTEE OF THE BRITISH OCCUPATIONAL HYGIENE SOCIETY. Biochemical threshold for trichloroethylene. Ann. occup. hyg. 17 (1974) 169.

318. SUN, M. W. Fluoride ion activity electrode for determination of urinary fluoride. $A m$ ind. hyg. assoc. j. 30 (1969) 133.

319. SUN, M. W., STEIN, E. and GRUEN, F. A single column method for the determination of urinary, $\delta$-aminolevulinic acid. Clin. chem. 15 (1969) 183.

320. SUNDERMAN, F. W., Jr. Measurements of nickel in biological material by atomic absorption spectrophotometry. Am. $j$. clin. pathol. 44 (1965) 182.
321. SUNDERMAN, F. W., Jr. Spectrophotometric measurements of serum nickel. Clin. chem. 13 (1967) 115.

322. SUNDERMAN, F. W. Nickel poisoning. In: F. W. SUNDERMAN and F. W. SUNDERMAN, Jr. (eds.), Laboratory diagnosis of diseases caused by toxic agents. Warren H. Green Inc., St Louis, Mo. 1970, p. 387.

323. SUNDERMAN, F. W., Sr. The treatment of acute nickel carbonyl poisoning with sodium diethyldithiocarbamate. Ann. clin. res. 3 (1971) 182.

324. SUZUKI, M. and WACKER, W. E. C. Determiantion of manganese in biological materials by atomic absorption spectroscopy. Anal. biochem. 57 (1974) 605 .

325. SZADKOWSKI, D., SCHRÖTER, V., ESSING, H. G., SCHALLER, K. H. and LEHNERT, G. Ein gaschromatographisches Nachweisverfahren für Benzol und Toluol in kleinsten Blutproben. Int. arch. occup. health 27 (1971) 300.

326. TANAKA, S. and IKEDA, M. A method for determination of trichloroethanol and trichloroacetic acid in urine. $B r . j$. ind. med. 25 (1968) 214.

327. TANAKA, S. and LIEBEN, J. Manganese poisoning and exposure in Pennsylvania. Arch. environ. health 19 (1969) 674.

328. TEISINGER, J. and FISEROVA-BERGEROVÁ, V. Valeur comparée de la détermination des sulfates et du phénol contenus dans l'urine pour l'évaluation de la concentration du benzène dans l'air. Arch. mal. prof. med. tra. secur. soc. 16 (1955) 221.

329. TEISINGER, J. New advances in the toxicology of carbon disulfide. $A m$. ind. hyg. assoc. j. 35 (1974) 55.

330. TICHY, M. and ICKRT, M. Manganese transfer into the bile in rats. Arch. ioxicol. 29 (1972) 51.

331. TIPTON, I. H., COOK, M. J., STEINER, R. L., BOYE, C. A., PERRY, H. M., Jr. and SCHROEDER, H. A. Trace elements in human tissue: I. Methods. Health phys. 9 (1963) 89.

332. TOLA, S., HERNBERG, S., ASP, S. and NIKKANEN, J. Parameters indicative of absorption and biological effect in new lead exposure: A prospective study. $B r$. $j$. ind. med. 30 (1973) 134.

333. TOLOT, F., SOUBRIER, R., BRESSON, J. R. and GIRARD, R. Diagnostic et traitement actuels du saturnisme. Arch. mal. prof. med. tra. secur. soc. 30 (1969) 675.

334. TOMOKUNI, K. and OGATA, M. Simple method for determination of urinary $\delta$-aminolevulinic acid as an index of lead exposure. Clin. chem. 18 (1972) 1534.

335. TOMPSETT, S. L. and FITZPATRICK, J. The nickel and molybdenum content of "normal" human urine and feces. Analyst (Londion) 75 (1950) 279.

336. TREON, J. F, Alcohols. In: F. A. Patty (ed.), Industrial hygiene and toxicology (2nd revised edition). Volume II. Toxicology. Interscience Publishers, New York, N.Y. 1963, pp. 1409-1422.

337. TRUHAUT, $R$. and BOUDENE, C. Une 
méthode simple de dosage du chrome dans l'urine. Arch. mal. prof. med. tra. secur. soc. 23 (1962) 786.

338. TRUJILLO, P., STEIN, $P$, and CAMPBELL, E. The preservation and storage of urine samples for the determination of mercury. Am. ind. hyg. assoc. j. May (1974) 257.

339. TUSL, J. Direct determination of fluoride in human urine using fluoride electrode. Clin. chim. acta 27 (1970) 216.

340. URONE, P. F, and ANDERS, H. K. Determination of small amounts of chromium in human blood, tissues and urine: Colorimetric method. Anal. chem. 22 (1950) 1317.

341. VALLOTON, M. N. and LOB, M. Absorption cutanée de mercure lors de l'utilisation d'un savon antiseptique par le personnel hospitalier. Schweiz. Med. Wochenschr. 103 (1973) 1455.

342. VANDEKAR, $M$. and WILFORD, $K$. The effect on cholinesterase activity of storage of undiluted whole blood sampled from men exposed to 6-isopropoxyphenyl methylcarbamate (OMS-33) Bull. WHO 40 (1969) 91.

343. VAN HAAFTEN, A. B. and SIE, S. T. The measurement of phenol in urine by gas chromatography as a check on benzene exposure. Am. ind. hyg. assoc. j. 26 (1965) 52.

344. VAN HOUTE, G. and COCLE, P. Proposition d'un nouveau test simple plus fidèle de dépistage du saturnisme. Arch. mal prof. med. tra. secur. soc. 30 (1969) 675.

345. VAN ORMER, D. G. and PURDY, W. C. The determination of manganese in urine by atomic absorption spectrometry. Anal. chim. acta 64 (1973) 93

346. VAN PETEGHEM, T. Over de waarde van de biologische test by het opsporen van verhoogde loodopname by de mens. Arch. bel. med. soc. 32 (1974) 136.

347. VASAK, V. Hodnoceni expozice zamestnaniu proctredi zneiisteném param scrouhliku [Assessment of exposure of workers to carbon disulphide vapours]. Prac. lek. 15 (1963) 143.

248. VENS, M. D. and LAUWERYS, R. Détermination simultanée du plomb et du cadmium dans le sang et l'urine par le couplage des techniques de chromatographie sur résine échangeuse d'ions et de spectrophotométrie d'absorption atomique. Arch. mal. prof. med. tra. secur. soc. 33 (1972) 97.

349. VICKER, S. and STUART, E. K. Simple, sensitive spectrophotofluorometric method for hydrazine in plasma. Anal. chem. 46 (1974) 138.

350. VIGNOLI, L., CRISTAU, B., DEFRETIN, J. P. and VIGNOLI, R. Microdosage photocolorimétrique de l'oxyde de carbone dans le sang par le chlorure de palladium et le réactif phosphomolybdotungstique de Folin et de Ciocalteu. Arch. mal. prof. med. tra. secur. soc. 21 (1960) 432.

351. VITALE, L. F., FINE, B. P., BARTH, A. and FILKIN, K. Urinary excretion of delta-aminolevulinic acid after discontinuance of therapy for lead poisoning. J. pediatr. 81 (1972) 977.

352. WADA, O., TOYOKAWA, K., URATA, G., YANO, Y. and NAKAO, K. A simple method for the quantitative analysis of urinary delta-aminolevulinic acid to evaluate lead absorption. $B r$. $j$. ind. med. 26 (1969) 240.

353. WALD, N., HOWARD, S., SMITH, P. G. and KJELDSEN, K. Association between atherosclerotic diseases and carboxyhaemoglobin levels in tobacco smokers. Brit. med. j. 1 (1973) 76.

354. WALDMAN, R. K. and KROUSE, L. A. A rapid routine method for determination of paranitrophenol in urine. Occup. health 12 (1952) 37.

355. WALDROM, H. A. Correlation between some parameters of lead absorption and lead intoxication. $\mathrm{Br} . j$. ind. med. 28 (1971) 195.

356. WALKLEY, J. E., PAGNOTTO, L. D. and ELKINS, H. B. The measurement of phenol in urine as an index of benzene exposure. Am. ind. hyg. assoc. j. 22 (1961) 362.

357. WATROUS, R. M. and MC CAUGHEY, M. B. Occupational exposure to arsenic in the manufacture of arsphenamine and related compounds. Ind. med. 14 (1945) 639.

358. WAWSCHINEK, O. Die Bestimmung kleiner chrommengen in Harn. Arch. toxicol. (Berl.) 22 (1971) 222.

359. WHITEHEAD, T. P. and WORTHINGTON, S. The determination of carboxyhaemoglobin. Clin. chim. acta 6 (1961) 356.

360. WHITLOCK, C. M., Jr., AMUSO, S. J. and BITTENBENDER, J. B. Chronic neurological disease in two manganese steel workers. Am. ind. hyg. assoc. j. 27 (1966) 454.

361. WHILHELM, K., VANDEKAR, $M$. and REINER, E. Comparison of methods for measuring cholinesterase inhibition by carbamates. Bull. WHO 48 (1973) 41.

362. WILLIAMS, R. T. Detoxication mechanism. Chapman and Hall, London 1959.

363. WILLIAMS, M. K. Blood lead and haemoglobin in lead absorption. Br. j. ind. med. 23 (19:66) 23.

364. WILLIAMS, M. $K$. and FEW, J. D. A simplified procedure for the determination of urinary $\delta$-aminolevulinic acid. $\mathrm{Br}$. j. ind. med. 24 (1967) 294.

365. WILLIAMS, M. K., KING, E. and WALFORD, J. Method for estimating objectively the comparative merits of biological tests of lead exposure. Br. med. $j .1$ (1968) 618.

366. WILLIAIMS, MI. K., KING, E. and WALFORD, J. An investigation of lead absorption in an electric accumulator factory with the use of personal samplers. Br. j. ind. med. 26 (1969) 202.

367. WITHEY, R. J. and MARTIN, L. A sensitive micro-method for the analysis of benzene in blood. Bull. environ. contam. toxicol. 12 (1974) 659 . 
368. WITTER, R. W. Measurement of blood cholinesterase. Arch. environ. health 6 (1963) 537.

369. WOLFE, H. R., DURHAM, W. F. and ARMSTRONG, J. F. Urinary excretion of insecticide metabolites: Excretion of paranitrophenol and DDA as indicators of exposure to parathion and DDT. Arch. environ. health 21 (1970) 711.

370. WORDEN, A. N. Toxicity of telodrin. Toxicol appl. pharmacol. 14 (1969) 556.
371. YLLNER, S. Metabolism of 1,1,1,2-tetrachloroethane in the mouse. Acta pharmacol. toxicol. (Kbh.) 29 (1971) 471.

372. ZENZ, C. and BERG, B. A. Human responses to controlled vanadium pentoxide exposure. Arch. environ. health 14 (1967) 709.

373. ZIELHUIS, R. L. Interrelationship of biochemical responses to the absorption of inorganic lead. Arch. environ. health, 23 (1971) 299.

Received for publication: 1975-04-11 